Cover photographs: Upper left, pulp and paper mill in southeastern Mississippi (photograph by Henry Folmar, MDEQ); center left, Mississippi Department of Environmental Quality employees releasing a sturgeon (photograph by Eleana Turner, MDEQ); bottom left, Mississippi Department of Environmental Quality employees setting hoop nets in the Leaf River (photograph by Eleana Turner, MDEQ); bottom right, Mississippi Department of Environmental Quality employees electrofishing (photograph by Barbara Kleiss, USGS); center right, Mississippi Department of Environmental Quality employees sorting catfish (photograph by Billy Justus, USGS); upper right, Mississippi Department of Environmental Quality employee filleting fish for dioxin analysis (photograph by Billy Justus, USGS) 


\section{Methods and Results of Dioxin Related Studies on the Leaf and Pascagoula Rivers, Mississippi, 1989-97}

By B.G. Justus, H.G. Folmar, and P.B. Bass

U.S. Geological Survey

Water-Resources Investigations Report 99-4102

Prepared jointly by the U.S Geological Survey and the Mississippi Department of Environmental Quality Office of Pollution Control

Pearl, Mississippi 1999 


\section{U.S DEPARTMENT OF THE INTERIOR \\ BRUCE BABBITT, Secretary}

\section{U.S. GEOLOGICAL SURVEY}

Charles G. Groat, Director

Any use of trade, product, or firm names is for identification purposes only and does not constitute endorsement by the U.S. Geological Survey.

For additional information write to:

District Chief

U.S. Geological Survey 308 South Airport Road

Pearl, MS 39208-6649
Copies of this report can be purchased from:

U.S. Geological Survey

Branch of Information Services

Box 25286, Federal Center

Denver, CO 80225-0286 


\section{CONTENTS}

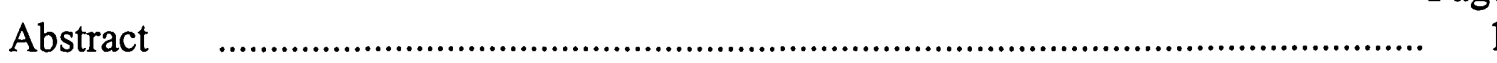

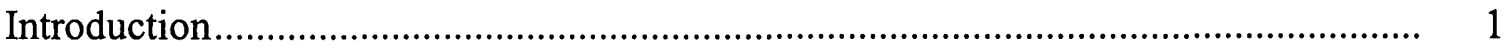

Purpose and Scope....................................................................................... 4

Description of the Study Area ........................................................................... 4

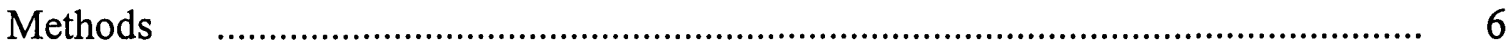

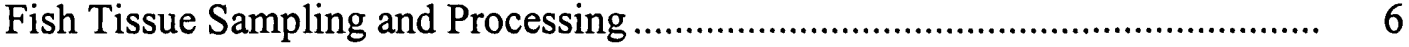

Mississippi Cooperative Dioxin Study ........................................................... $\quad 6$

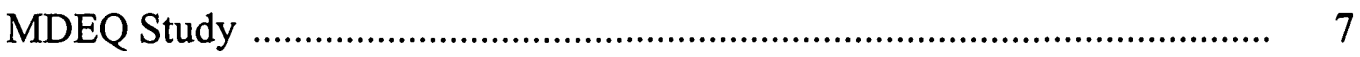

Sampling Methods and Frequencies.......................................................... 7

Sample Processing and Shipping ........................................................... 9

Effluent Sampling and Processing …………………….................................... 9

Caddisfly Sampling and Processing ............................................................. $\quad 10$

Streambed-Sediment Sampling and Processing ................................................. $\quad 10$

Laboratory Analysis .................................................................................... 11

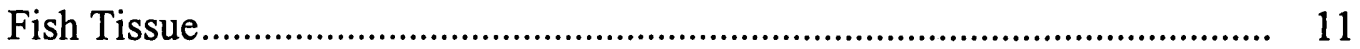

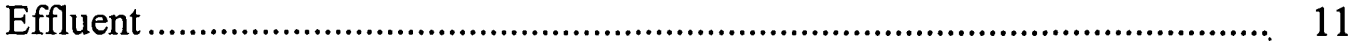

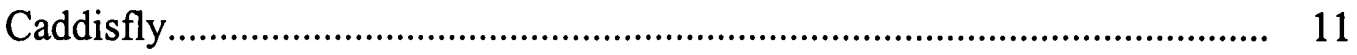

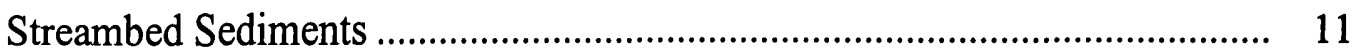

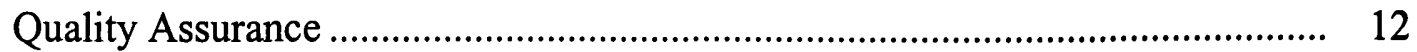

Developing Criteria for Fish-Consumption Advisories......................................... 13

Results and Discussion ............................................................................... 15

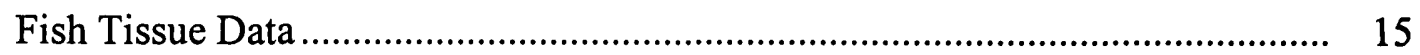

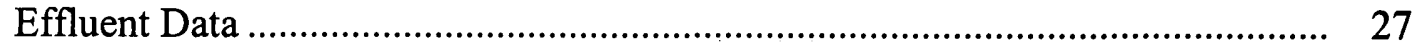

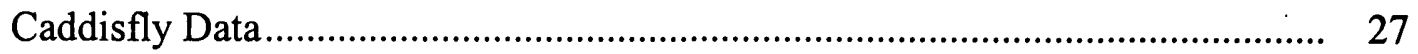

Streambed-Sediment Data........................................................................... 27

Fish-Consumption Advisories......................................................................... $\quad 31$

Summary and Conclusions ................................................................................. 33

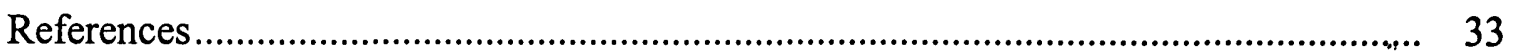




\section{FIGURES}

1. Chronology of events leading to dioxin studies on the Leaf and Pascagoula Rivers, Mississippi.

Page

2. Map showing location of sites sampled for dioxin on the Leaf and Pascagoula

Rivers, 1989-97

3. Graph showing concentrations of $2,3,7,8$ TCDD in channel catfish samples collected from three sites on the Leaf River, Mississippi, 1989-97

4. Graph showing concentrations of 2,3,7,8 TCDD in flathead catfish samples collected from four sites on the Leaf River, Mississippi, 1990-97.

5. Graph showing concentrations of 2,3,7,8 TCDD in flathead and channel catfish collected from four sites on the Leaf River, Mississippi, 1990-96 26

6. Description of fish advisories for the Leaf and Pascagoula Rivers, 1989-96... 32

\section{TABLES}

1. International toxicity equivalency factors for dioxin congeners analyzed in fish and sediment samples collected from the Leaf and Pascagoula Rivers, Mississippi, 1989-97.

2. Sites sampled for fish tissue and streambed sediment as part of the Mississippi Cooperative Dioxin Study, 1989

3. Fish tissue sampling sites for dioxin on the Leaf and Pascagoula Rivers, Mississippi, 1990-97...

4. Sites where sediments were sampled for dioxins in the Pascagoula River Basin in 1990 and 1992

5. Analytes for dioxin samples of fish tissue, sediment, mill effluent, and caddisflies collected from the Leaf and Pascagoula Rivers, 1989-97

6. U.S. Food and Drug Administration action levels for 2,3,7,8 tetraclorodibenzo-p-dioxin, and criteria used by three southeastern States for issuing consumption advisories for fish tissue.

7. Common names of fish species and information for fish samples collected for dioxin analysis from the Leaf and Pascagoula Rivers, 1989-97

8. Concentrations of 2,3,7,8 tetracloro-dibenzo-p-dioxin (TCDD) and 2,3,7,8 tetraclorodibenzofuran (TCDF) in fish tissue samples from the Leaf River Basin for the Mississippi Cooperative Dioxin Study, 1989

9. Weighted mean concentrations of 2,3,7,8 tetracloro-dibenzo-p-dioxin (TCDD) and 2,3,7,8 tetraclorodibenzofuran (TCDF) in fish tissue samples from the Leaf and Pascagoula Rivers, Mississippi, 1990.

10. Weighted mean concentrations of 2,3,7,8 tetracloro-dibenzo-p-dioxin (TCDD) and 2,3,7,8 tetraclorodibenzofuran (TCDF) in fish tissue samples from the Leaf and Pascagoula Rivers, Mississippi, 1991 


\section{TABLES-Continued}

11. Weighted mean concentrations of 2,3,7,8 tetracloro-dibenzo-p-dioxin (TCDD) and 2,3,7,8 tetraclorodibenzofuran (TCDF) in fish tissue samples from the Leaf and Pascagoula Rivers, Mississippi, 1992

12. Weighted mean concentrations of 2,3,7,8 tetracloro-dibenzo-p-dioxin (TCDD) and 2,3,7,8 tetraclorodibenzofuran (TCDF) in fish tissue samples from the Leaf and Pascagoula Rivers, Mississippi, 1993

13. Weighted mean concentrations of 2,3,7,8 tetracloro-dibenzo-p-dioxin (TCDD) and 2,3,7,8 tetraclorodibenzofuran (TCDF) in fish tissue samples from the Leaf and Pascagoula Rivers, Mississippi, 1994

14. Weighted mean concentrations of 2,3,7,8 tetracloro-dibenzo-p-dioxin (TCDD) and 2,3,7,8 tetraclorodibenzofuran (TCDF) in fish tissue samples from the Leaf and Pascagoula Rivers, Mississippi, 1995

15. Weighted mean concentrations of 2,3,7,8 tetracloro-dibenzo-p-dioxin (TCDD) and 2,3,7,8 tetraclorodibenzofuran (TCDF) in fish tissue samples from the Leaf and Pascagoula Rivers, Mississippi, 1996.

16. Concentrations of 2,3,7,8 tetracloro-dibenzo-p-dioxin (TCDD) and 2,3,7,8 tetraclorodibenzofuran (TCDF) in fish tissue samples from the Leaf and Pascagoula Rivers, Mississippi, 1997

17. Concentrations of 2,3,7,8 tetracloro-dibenzo-p-dioxin (TCDD) and 2,3,7,8 tetraclorodibenzofuran (TCDF) in water samples collected from a paper mill effluent discharging into the Leaf River, January 1993 - October 1994 ... 27

18. Concentrations of 2,3,7,8 tetrachlorodibenzo-p-dioxin (TCDD) and 2,3,7,8 tetrachlorodibenzofuran (TCDF) for caddisfly larvae samples collected from the Pascagoula River Basin, Mississippi from 1989-96.

19. Concentrations of 2,3,7,8 tetrachlorodibenzo-p-dioxin (TCDD), 2,3,7,8, tetrachlorodibenzofuran (TCDF), and total organic carbon (TOC) in sediment samples collected from the Leaf River Basin, Mississippi, 1989 .... 29

20. Concentrations of dioxin congeners for sediment samples collected on the Leaf and Pascagoula Rivers, Mississippi, November 1992. 



\title{
Methods and Results of Dioxin Related Studies on the Leaf and Pascagoula Rivers, Mississippi, 1989-97
}

\author{
By B.G. Justus ${ }^{1}$, H.G. Folmar', and P.B. Bass ${ }^{3}$
}

\section{ABSTRACT}

In January 1989, the Mississippi Department of Environmental Quality began the Mississippi Cooperative Dioxin Study after earlier studies in the United States had linked dioxins in fish tissue to the bleaching process at paper mills. In February 1989, the United States Environmental Protection Agency began releasing results of analyses of samples collected in 1988 for the National Study of Chemical Residues in Fish. One whole-body channel catfish sample collected from a site on the Leaf River at New Augusta, Mississippi, had 99 parts per trillion of 2,3,7,8 tetrachlorodibenzo-p-dioxin (2378 TCDD), the fifth highest concentration in samples from 388 sites throughout the United States. Based on these data and on data collected for the Mississippi Cooperative Dioxin Study, the Mississippi Department of Environmental Quality issued a fish consumption advisory in November 1989 for a 12-mile reach of the Leaf River. From 1989 to 1997, dioxins were monitored annually on the Leaf River, and during selected years, sites farther downstream in the Pascagoula River were also sampled. This report documents methods used to monitor dioxins, particularly 2378 TCDD, in fish, macroinvertebrates, streambed sediment, and mill effluent; changes of dioxin concentrations in fish and macroinvertebrate tissue; methods used to develop dioxin criteria; and the rationale for issuing fishconsumption advisories.

Of the 75 dioxin congeners, 2378 TCDD has been the most studied, largely because it is suspected to have a high potential for bioaccumulation in the environment and little is known concerning its half-life in stream ecosystems. Results of this study indicate that 2378 TCDD concentrations in fish and aquatic macroinvertebrate tissue decreased rapidly in the Leaf and Pascagoula Rivers after major sources were eliminated. Three factors that may have influenced, or interacted to accelerate, the decrease of 2378 TCDD in fish tissue after the major source was eliminated are flushing of contaminated sediments by streamflow; depuration by aquatic organisms; and a short half-life of the contaminant in fish tissue, sediment, or both.

\section{INTRODUCTION}

There are approximately 75 polychlorinated dibenzo-p-dioxins (PCDDs) and 135

polychlorinated dibenzofuran (PCDFs) congeners, all of which are considered toxic and bioaccumulate to different degrees. Each congener is distinguished by chlorine-atom positioning on two benzene rings. Most samples for the studies described in this report were analyzed for the 2,3,7,8 tetrachlorodibenzo-p-

1 U.S. Geological Survey, Pearl, Mississippi

${ }^{2}$ Mississippi Department of Environmental Quality, Office of Pollution Control, Pearl, Mississippi

${ }^{3}$ Mississippi Department of Environmental Quality, Office of Pollution Control, Jackson, Mississippi 
dioxin (2378 TCDD) and 2,3,7,8

tetrachlorodibenzofuran (2378 TCDF) congeners.

The 2378 TCDD congener has been the most studied dioxin congener and has been described as being the most toxic chemical that EPA has tested (U.S. Environmental Protection Agency, 1992a). However, toxicity to different animal species varies widely. Also, there is little available information and much controversy concerning the carcinogenicity and the ability of 2378 TCDD to disrupt reproductive processes. The 2378 TCDD congener is suspected to have a high potential for bioaccumulation in the environment (U.S.

Environmental Protection Agency, 1992a). Little is actually known about the half-life of 2378

TCDD in stream ecosystems, but some data exist from tests done in laboratories and lake environments. Although the 2378 TCDF congener is only one-tenth as toxic as the 2378 TCDD congener (table 1; Barnes and Bellin, 1989), it is often detected in greater concentrations and can contribute a substantial part of total dioxin toxicity.

A chronology of events leading up to the studies is given in figure 1 and is discussed below. Dioxin compounds were first identified in the early 1960's as contaminants in Agent Orange, a defoliant best known for its use in Vietnam. In the 1970 's, evidence began to mount showing that dioxin is toxic and possibly carcinogenic, and different dioxin compounds were identified from various media sampled throughout the United States.

In 1984, the EPA began the National Dioxin Study. To assist the EPA with this study, the Mississippi Department of Environmental Quality (MDEQ) collected fish at seven randomly selected sites in Mississippi (no sites were sampled on the Leaf River). Results from the National Dioxin Study (U.S. Environmental Protection Agency, 1987) were the first official data to link dioxin in fish tissue to bleach-kraft paper mills. By 1988, it had been determined that dioxin could be generated as a by-product of bleaching processes of paper mills (U.S. Environmental Protection Agency, 1988), and in the same year the EPA began the National Study of Chemical Residues in Fish. The MDEQ also collected fish for this study, and one of the sites sampled was the Leaf River near New Augusta, Mississppi.

Table 1. International toxicity equivalency factors (TEFs) for the dioxin congeners analyzed in fish and sediment samples collected from the Leaf and Pascagoula Rivers, Mississippi, 1989-97 [modified from Barnes and Bellin, 1989]

\begin{tabular}{lrll}
\hline \multicolumn{1}{c}{ Congener } & \multicolumn{2}{c}{ Abbreviation } & TEF \\
\hline 2,3,7,8 tetrachloro-dibenzofuran & 2378 & TCDF & 0.1 \\
$2,3,7,8$ tetrachloro-dibenzodioxin & 2378 & TCDD & 1 \\
$1,2,3,7,8$ pentachloro-dibenzofuran & 12378 & PECDF & 0.05 \\
2,3,4,7,8 pentachloro-dibenzofuran & 23478 & PECDF & 0.05 \\
$1,2,3,7,8$ pentachloro-dibenzodioxin & 12378 & PECDD & 0.5 \\
$1,2,3,4,7,8$ hexachloro-dibenzofuran & 123478 & HXCDF & 0.1 \\
$1,2,3,6,7,8$ hexachloro-dibenzofuran & 123678 & HXCDF & 0.1 \\
$2,3,4,6,7,8$ hexachloro-dibenzofuran & 234678 & HXCDF & 0.1 \\
$1,2,3,7,8,9$ hexachloro-dibenzofuran & 123789 & HXCDF & 0.1 \\
$1,2,3,4,7,8$ hexachloro-dibenzodioxin & 123478 & HXCDD & 0.1 \\
$1,2,3,6,7,8$ hexachloro-dibenzodioxin & 123678 & HXCDD & 0.1 \\
$1,2,3,7,8,9$ hexachloro-dibenzodioxin & 123789 & HXCDD & 0.1 \\
$1,2,3,4,6,7,8$ heptachloro-dibenzofuran & 1234678 & HPCDF & 0.01 \\
$1,2,3,4,7,8,9$ heptachloro-dibenzofuran & 1234789 & HPCDF & 0.01 \\
$1,2,3,4,6,7,8$ heptachloro-dibenzodioxin & 1234678 & HPCDD & 0.01 \\
$1,2,3,4,6,7,8,9$ octachloro-dibenzofuran & 12346789 & OCDF & 0.001 \\
$1,2,3,4,6,7,8,9$ octachloro-dibenzodioxin & 12346789 & OCDD & 0.001 \\
\hline
\end{tabular}


1960's - Dioxins are identified in Agent Orange.

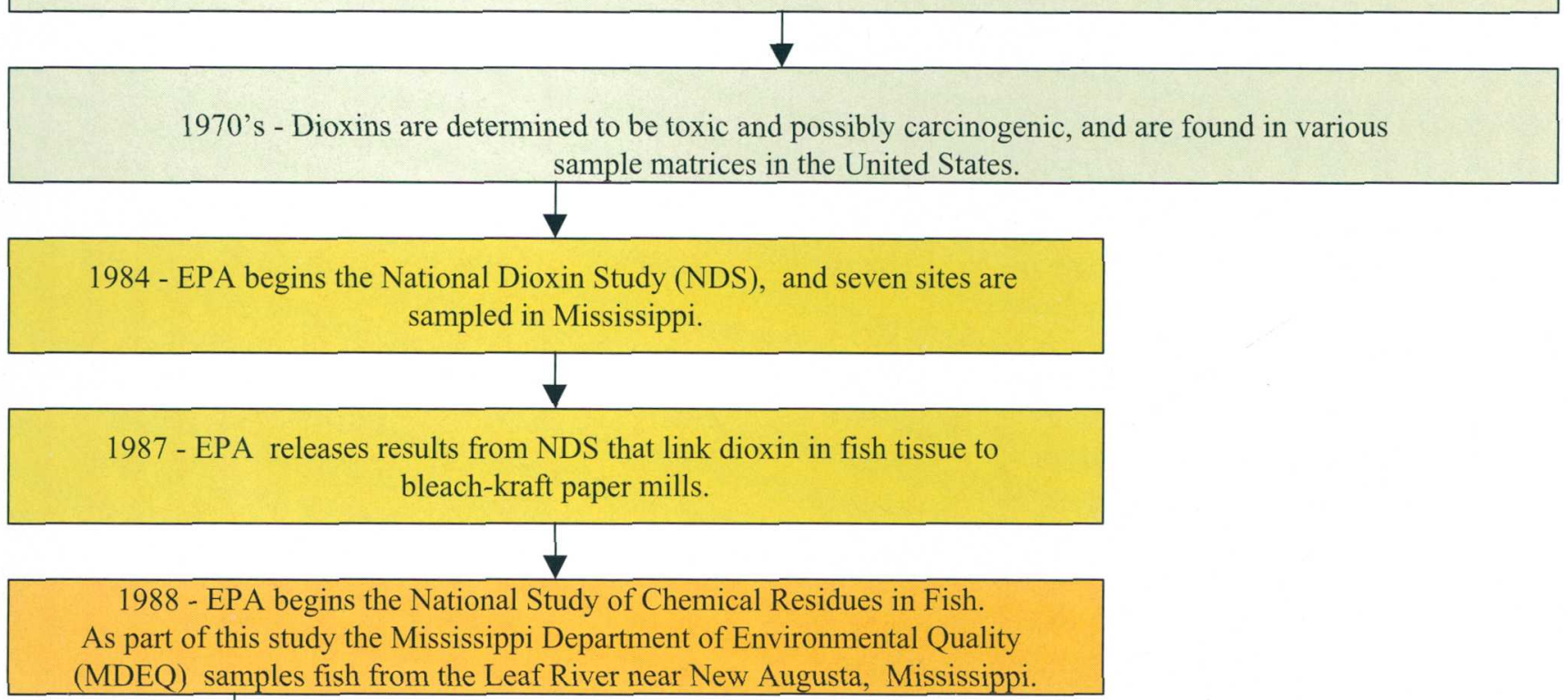

January 1989 - MDEQ requests that paper mills in Mississippi sample for dioxins near mill effluents as part of the Mississippi Cooperative Dioxin Study.

February 1989 - EPA releases results from the National Study of Chemical Residues in Fish. One channel catfish sample has 99 parts per trillion 2378 TCDD.

Leaf River concentrations are fifth highest of 388 sites sampled.

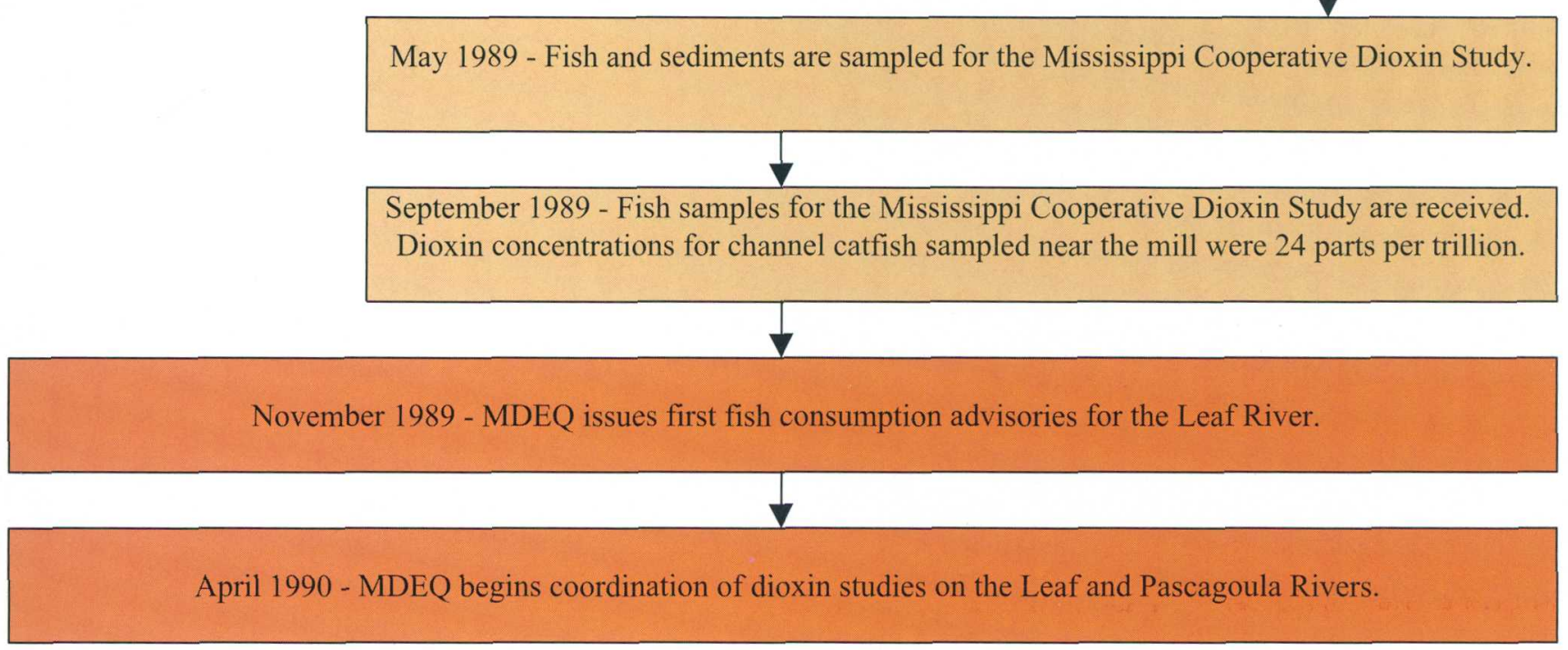

Figure 1. Chronology of events leading to dioxin studies on the Leaf and Pascagoula Rivers, Mississippi. 
In January 1989, before results of the National Study of Chemical Residues in Fish were received, the MDEQ met with representatives from paper mills in Mississippi to ask the mills to sample fish and sediments upstream and downstream from their respective effluents as part of the Mississippi Cooperative Dioxin (MCD) Study. Five of the seven paper mills in the State, including the mill on the Leaf River, complied with the request. The following month, the EPA released whole-body catfish data as part of the National Study of Chemical Residues (U.S. Environmental Protection Agency, 1992a). The site on the Leaf River at New Augusta, Mississippi, had the fifth highest concentration of 2378 TCDD among 388 sites sampled throughout the United States. Two samples of whole-body catfish contained 99 and 83 parts per trillion (pg/g) of 2378 TCDD.

Sampling for the MCD Study was completed in September 1989. A fillet sample of channel catfish from a site just downstream of the mill effluent had $24 \mathrm{pg} / \mathrm{g} 2378$ TCDD, nearly equal to the U.S. Food and Drug Administration (FDA) action level of $25 \mathrm{pg} / \mathrm{g}$ in edible portions (U.S. Food and Drug Administration, 1992). [The FDA also suggests that no fish be consumed when dioxin concentrations exceed $50 \mathrm{pg} / \mathrm{g}$ (U.S. Food and Drug Administration, 1992)]. These levels were established to protect consumers from contaminated products in the market place.

The EPA Region IV did not consider FDA action levels to be protective of local recreational and subsistence anglers and special populations at high risk (such as pregnant women and young children). The EPA suggested that the MDEQ use a more conservative level of protection than the FDA levels, but they did not recommend actual concentrations as criteria. Because of controversy surrounding the toxicity, the carcinogenicity, and the extent of disruption to reproductive processes by $2378 \mathrm{TCDD}$, the MDEQ agreed initially that it should approach the issue aggressively and that advisories should be as protective as possible.

In November 1989, fish-consumption advisories were issued for a 12-mile reach of the Leaf River from State Highway 29 (Hwy 29) near New Augusta, Mississippi, downstream to State Highway 15 (Hwy 15) near Beaumont (fig. 2). In 1990, the MDEQ assumed responsibility for monitoring and began intensively sampling fish tissue from the Leaf River for dioxin. Later that year, the agency received funding from a paper mill on the Leaf River to support dioxin monitoring. Since 1990, that same mill has continued to annually fund the MDEQ for monitoring dioxins. The MDEQ developed annual monitoring plans and expanded sampling to address dioxin concentrations in sediment and industrial effluent. To determine 2378 TCDD and 2378 TCDF concentrations in secondary food chain organisms (and amounts being transferred through the food chain), the mill chose to monitor dioxins in aquatic macroinvertebrate (caddisfly) tissue from sites in the study area.

The primary objectives of this study were to document dioxin concentrations in the different sample media and to use dioxin data as a basis for issuing and modifying fishconsumption advisories. Data collected prior to 1992 also proved useful for determining the effects of an accidental sludge spill in 1992 that depleted oxygen in the Leaf River and resulted in a large fish kill. There was some public speculation that the spill also introduced dioxins to the stream.

\section{Purpose and Scope}

The purpose of this report is to document the sequence of events related to dioxin monitoring in the Leaf and Pascagoula Rivers in southeastern Mississippi, and to document study methods and results. The report, prepared jointly by the U.S. Geological Survey and the MDEQ, Office of Pollution Control, addresses fish, sediment, effluent, and caddisfly sampling from 1989 to 1997. Also provided are a description of the methods used to develop dioxin criteria and explanations for rationale used to issue fishconsumption advisories.

\section{Description of the Study Area}

The study area extends from the Leaf River just upstream from the confluence of the Leaf and Bowie Rivers near Hattiesburg, downstream to the confluence of the Pascagoula River and Black Creek (fig. 2). The Leaf and Pascagoula Rivers both lie in the Southeastern 


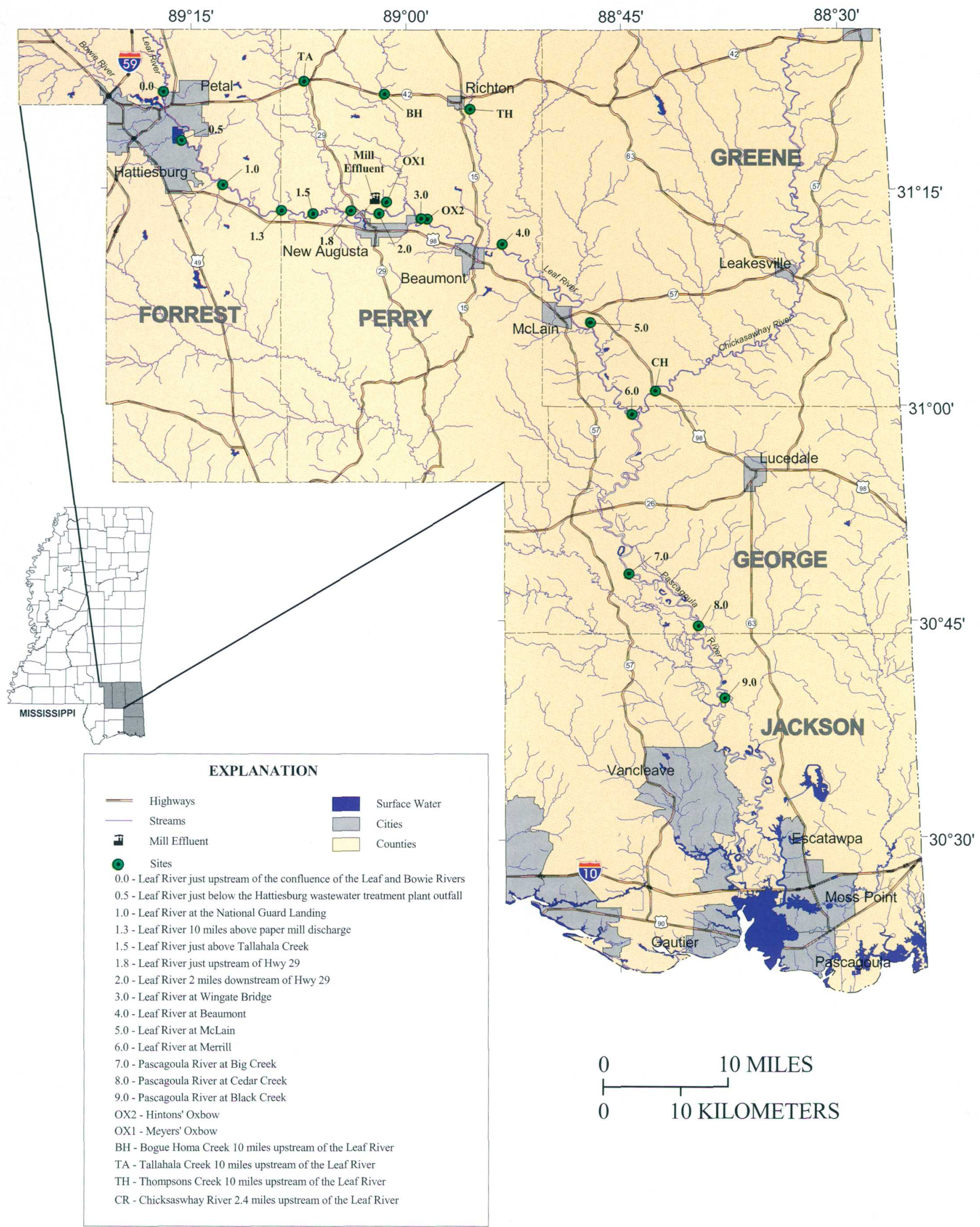

Figure 2. Location of sites sampled for dioxin on the Leaf and Pascagoula Rivers, 1989-97. 5 
Plains Ecoregion and flow generally southeastward to the Gulf of Mexico. All tributaries to the Pascagoula River are blackwater streams (meaning that tannins and lignins from decaying wood and foliage naturally stain the water) that are slightly acidic under low-flow conditions.

\section{METHODS}

Because the MDEQ developed fish and sediment sampling protocols for the MCD Study, there was some overlap with the methods MDEQ used for later monitoring. Methods for the MCD Study and for MDEQ monitoring are discussed separately for each medium in the following pages.

\section{Fish Tissue Sampling and Processing}

\section{Mississippi Cooperative Dioxin Study}

Eight sites were sampled for the MCD Study (table 2). The MDEQ developed sampling protocols for the MCD Study; however, fish were sampled by a contractor. A fillet composite of individuals of a bottom-feeding fish species and a fillet composite of individuals of a game fish species were targeted at each site (Phil Bass, Mississippi Department of Environmental Quality, written commun., 1989). Targeted bottom-feeding fish were channel catfish, blue catfish, bullhead, buffalo, and carp. Targeted game fish were largemouth bass, crappie, spotted bass, white bass, chain pickerel, and bluegill. Fish species targeted for sampling by the MCD Study were selected because they were known to bioaccumulate contaminants such as dioxin (Eisler, 1986), or because of commercial or recreational importance. Fish sizes targeted were typical of the sizes harvested by recreational or commercial anglers.

Inclement weather in spring 1989 hampered fish sampling for the MCD Study. Fish were not collected in large numbers, and samples were not comprised solely of the targeted species. Instead, essentially all individuals of any species that were large enough to be filleted were collected, and many samples were comprised of fish smaller than the targeted size range. As a supplemental collection for the MCD Study, catfish were collected by hook-and-line in August 1989 by mill employees.

Table 2. Sites sampled for fish tissue and streambed sediment as part of the Mississippi Cooperative Dioxin Study, 1989

\begin{tabular}{llc}
\hline & Site number and name & $\begin{array}{c}\text { Distance } \\
\text { from mill } \\
\text { discharge } \\
\text { (river miles) }\end{array}$ \\
\hline 0.5 & Leaf River just below the Hattiesburg wastewater treatment plant outfall & -22 \\
1.3 & Leaf River 10 miles above paper mill discharge & -9 \\
2.0 & Leaf River 2 miles downstream of Highway 29 & 2 \\
3.0 & Leaf River at Wingate Bridge & 5 \\
5.0 & Leaf River at McLain & 25 \\
TA & Tallahala Creek 10 miles upstream of the Leaf River & 14 \\
BH & Bogue Homa Creek 10 miles upstream of the Leaf River & 14 \\
TH & Thompsons Creek 10 miles upstream of the Leaf River & 23 \\
\hline
\end{tabular}




\section{MDEQ Study}

\section{Sampling Methods and Frequencies}

Thirteen sites were sampled for fish tissue during 1990-97, but sampling intensity and frequency changed throughout the years as the focus of the study evolved (table 3 ). The fish tissue sampling effort--sampling frequency and the number of sites sampled--was intensive from 1990 to 1992 , but decreased as the study progressed and concentrations of 2378 TCDD decreased. Sampling methods were modified as field personnel became more proficient at sampling targeted fish species.

In 1990, MDEQ assumed the responsibility of coordinating sampling for dioxins and was assisted in sampling by the Mississippi Department of Wildlife Fisheries and Parks (MDWFP) and by mill employees. The primary focus of the 1990 sampling effort was to collect fish species routinely eaten by the public, particularly catfish species. Catfish were of special interest to the MDEQ because they are preferred by recreational and commercial anglers, have been shown by previous studies to have high concentrations of dioxins (U.S.

Environmental Protection Agency, 1992a), have a high percentage of lipids to which contaminants such as dioxins will naturally adhere (Eisler, 1986), and feed on other fish.

Catfish were targeted for each of the three sampling efforts: spring, summer, and fall. Bass and other sunfish were targeted only in the fall sampling. Nine sites were sampled by electrofishing, hoop-netting, and trotlining, depending on the target species and the prevailing conditions.

Table 3. Fish tissue sampling sites for dioxin on the Leaf and Pascagoula Rivers, Mississippi, 1990-97

\begin{tabular}{|c|c|c|c|c|c|c|c|c|c|}
\hline \multirow{2}{*}{$\begin{array}{l}\text { Site } \\
\text { number }\end{array}$} & \multirow{2}{*}{$\begin{array}{l}\text { Distance } \\
\text { from mill } \\
\text { discharge } \\
\text { (river miles) }\end{array}$} & \multicolumn{8}{|c|}{ Sampling frequency } \\
\hline & & 1990 & 1991 & 1992 & 1993 & 1994 & 1995 & 1996 & 1997 \\
\hline 0.5 & -22 & 0 & 0 & 2 & 2 & 2 & 1 & 1 & 0 \\
\hline 1.0 & -12 & 3 & 3 & 2 & 0 & 0 & 0 & 0 & 0 \\
\hline 1.5 & -4 & 0 & 0 & 0 & 2 & 2 & 1 & 1 & 0 \\
\hline 2.0 & 2 & 3 & 3 & 2 & 2 & 2 & 1 & 1 & 1 \\
\hline 3.0 & 5 & 3 & 0 & 0 & 0 & 0 & 0 & 0 & 0 \\
\hline 4.0 & 12 & 3 & 3 & 2 & 2 & 2 & 1 & 1 & 1 \\
\hline 5.0 & 25 & 3 & 3 & 2 & 2 & 2 & 1 & 1 & 0 \\
\hline 6.0 & 40 & 3 & 3 & 2 & 2 & 2 & 1 & 0 & 0 \\
\hline 7.0 & 59 & 1 & 3 & 2 & 2 & 0 & 0 & 0 & 0 \\
\hline 8.0 & 66 & 1 & 0 & 2 & 0 & 0 & 0 & 0 & 0 \\
\hline 9.0 & 80 & 1 & 0 & 2 & 0 & 0 & 0 & 0 & 0 \\
\hline$O \times 1$ & 2 & 0 & 1 & 0 & 0 & 0 & 0 & 0 & 0 \\
\hline OX2 & 6 & 0 & 1 & 0 & 0 & 0 & 0 & 0 & 0 \\
\hline
\end{tabular}

a 0.5 Leaf River just below the Hattiesburg wastewater treatment plant outfall

1.0 Leaf River at the National Guard Landing

1.5 Leaf River just above Tallahala Creek

2.0 Leaf River 2 miles downstream of Highway 29

3.0 Leaf River at Wingate Bridge

4.0 Leaf River at Beaumont
5.0 Leaf River at McLain

6.0 Leaf River at Merrill

7.0 Pascagoula River at Big Creek

8.0 Pascagoula River at Cedar Creek

9.0 Pascagoula River at Black Creek

OX1 Meyers' Oxbow

OX2 Hintons' Oxbow 
Initially, trotlines were used for collecting channel catfish. Trotlines, bait, and trotline anchors were provided to each two- or threeperson team on the afternoon of the night intended for sampling. The teams would then travel to their respective site(s) and set trotlines near dusk. Fish were collected, and trotlines were re-baited periodically throughout the night. Fish were collected for the last time just after dawn. Although the trotline method was effective for sampling channel catfish, it was also very labor intensive. During daylight hours, sampling personnel ran hoop nets, re-set hoop nets, and electrofished to collect species other than channel catfish. After sampling was completed for the week, all fish were taken to the MDEQ laboratory for processing.

As the study progressed, the MDEQ began to rely on electrofishing as a primary sampling tool. There were several advantages of electrofishing over trotlining--fewer personnel were necessary, no overnight sampling was required, more fish species could be collected, and a greater range of sizes could be sampled for all species.

In 1990, the primary electrofishing tool for the MDEQ was a 12-volt battery powered, electric fence shocker originally manufactured for confining livestock. Electrical components of the fence shocker were modified to produce a pulsating frequency effective for collecting all sizes of blue and flathead catfish and small channel catfish (less than $1.2 \mathrm{lb}$ ). Two sections of standard (12 or 14 gauge) insulated electrical wire were connected to the positive pole of the fence shocker. The opposite end of each section of electrical wire was weighted to the stream bottom with 3 feet of bare, copper welding lead. The length of each of the two wires was approximately the same as the deepest sections of the stream intended for sampling. The cathode, a 6-foot section of electrical wire tied to a 3-inch piece of chain, was connected to the negative pole. When electrofishing, the anodes and cathodes were dropped over the side of the boat, and the anodes were dragged along the stream bottom behind the boat. The fence shocker was highly effective for collecting catfish when water temperatures exceeded $70^{\circ} \mathrm{F}$.

Fish were also sampled three times in

1991. Catfish were again targeted on all sampling occasions, whereas bass and sunfish were targeted only in the fall. The frequency and magnitude of the fish sampling effort early in the study prompted MDEQ personnel to update electrofishing equipment and to become more efficient at collecting fish. By the second collection in 1991, MDEQ personnel had reviewed much of the electrofishing literature and were having success electrofishing with conventional equipment for blue, channel, and flathead catfish. There were several advantages to using conventional electrofishing equipment instead of the fence shocker: less than 3 feet of anodes were in the water at any time which reduced snagging; because the electrodes were shorter, the boat could be moved quickly and more time could be spent electrofishing; and equipment could be adjusted to collect species other than catfish.

The MDEQ continued to use the 1991 fish sampling methods through 1997; fish were collected by electrofishing during the day, and if more fish were needed from the site, hoop nets were set during the night. Hoop nets were usually set in the evening and were checked for fish the following morning. Sampling was routinely done during the first 3 days of the workweek, and a two-person team would often collect fish from four sites in a day. Fish were processed during the 2 days remaining in the workweek; the time required to collect seasonal fish samples from all the sites ranged from 2 to 5 weeks. MDEQ personnel became more proficient at fish sampling as the study progressed, and methods used to electrofish for the three species of catfish with conventional equipment were published (Justus, 1994).

In 1992, fish sampling was reduced to two times per year--summer and fall. Catfish were targeted on both sampling occasions and bass and sunfish were targeted only in the fall. By 1993, the MDEQ had documented that 2378 TCDD concentrations in bass and sunfish were much lower than dioxin concentrations in catfish and were well below advisory levels; therefore, sampling of bass and sunfish was discontinued. It had also been determined that flathead catfish contained higher dioxin concentrations than channel and blue catfish. Concentrations of 2378 TCDD in smallmouth buffalo collected in 1992 were comparable to concentrations in flathead catfish; therefore, smallmouth buffalo were targeted in 1993. From 1994 to 1996, only 
flathead and channel catfish were sampled, and the MDEQ documented the decrease of dioxin in these species to below advisory levels. In 1997, the sampling effort was reduced; because the longest continuous data set existed for channel catfish, it was the only species targeted.

If the weight range of a targeted species commonly exceeded $5 \mathrm{lb}$, three size classes of that species were targeted. For fish species having a weight range frequently exceeding $10 \mathrm{lb}$ (such as flathead and blue catfish), the three size classes were fish near $4 \mathrm{lb}$, near $8 \mathrm{lb}$, and greater than $10 \mathrm{lb}$. For fish species not frequently exceeding $10 \mathrm{lb}$ (such as channel catfish and largemouth bass), the three size classes were fish near $1.5 \mathrm{lb}$, near $3 \mathrm{lb}$, and greater than $5 \mathrm{lb}$. For fish species that did not routinely exceed $1 \mathrm{lb}$, only one sample was collected prior to 1994. After 1994, when it had been documented that dioxin concentrations were decreasing, the smallest weight classes were no longer targeted.

For an optimum size class sample, three to five fish were collected with the smallest fish weighing no less than 75 percent of the largest fish in the composite. Because large fish were not abundant, it was not always possible to collect three fish belonging to the largest size class (greater than $10 \mathrm{lb}$ ), and samples were sometimes analyzed which had fewer than three fish. Once collected, fish were immediately placed on wet ice in a clean cooler that was labeled with the site number.

\section{Sample Processing and Shipping}

All samples collected after the MCD Study concluded were processed at the MDEQ laboratory. Samples were processed as follows:

- each fish collected at a site was tagged with a color coded, numbered tag;

- each fish was identified to species;

- each fish was weighed and measured;

- up to five fish of similar size were combined into a composite sample;

- a unique number was assigned to the composite sample;

- the sex of each fish in the sample was recorded;

- each fish in the sample was filleted, and all skin was removed;

- weights of the left-side and right-side fillets were recorded;
- individual fillets were wrapped in aluminum foil;

- each fillet was labeled with the tag number followed by an " $L$ " or " $R$ " which was determined by the side of the fish that the fillet came from;

- left- and right-side fillets of a composite sample were separated and placed in ziplock bags of appropriate size; and

- all samples were stored frozen until shipment.

Fish filleting was done on clean, solventrinsed, plastic cutting boards, on a solventrinsed aluminum table, or on a wooden table covered with aluminum foil that was replaced after all fish in the sample were filleted.

Bags with left-side fillets were shipped overnight to a contract laboratory for analysis while the right-side fillets were archived in case additional analyses were needed. When shipping samples to the contract laboratory, the left-side fillets belonging to a composite sample were bagged together and placed in a cooler (or coolers) along with the other composite samples collected at the site. A list of the samples contained in the cooler and $5 \mathrm{lb}$ of dry ice also accompanied the sample in the cooler. The contract laboratory was then notified that samples were being shipped, chain-of-custody forms were placed on the lid of the cooler, and the cooler was shipped to the laboratory by overnight delivery.

\section{Effluent Sampling and Processing}

Effluent samples were collected by the MDEQ from February 1993 to October 1994 at the paper mill that discharges into the Leaf River. Samples were collected monthly from February 1993 through January 1994; for the remainder of 1994, samples were collected quarterly. On each occasion, a 72-hour composite was made from samples collected hourly by an automatic sampler. Locks and chain-of-custody seals were placed on the automatic sampler to discourage tampering during sample collection. Samples were collected in 1-liter glass containers that were certified by the manufacturer to be free of dioxins. Sample blanks and duplicates were collected each time effluent samples were 
collected. All plastic tubing used to collect the effluent sample was replaced prior to sampling. After the tubing was replaced, de-ionized water was used to rinse the sampler. This rinsate was collected as a field blank to document any contamination in the sampler, in the new tubing, or in the sampling containers. Samples and field blanks were chilled on wet ice for transport to the laboratory. Once at the laboratory, samples were transferred to refrigeration units to await shipment.

\section{Caddisfly Sampling and Processing}

Caddisfly tissue was sampled by aquatic biologists contracted by the mill. On several occasions contractors were assisted by mill employees and by high school and college students. Caddisfly tissue was sampled semiannually beginning in 1989 and continued midway through June 1996. For the first sampling in 1989, only two sites were sampled: one just above and another just downstream of the mill discharge. For the second sampling in 1989, a third site was added downstream of the mill discharge. After 1989, five or more sites were sampled for caddisfly tissue.

Caddisfly larvae were collected by removing submerged woody debris from the stream and picking attached larvae. Larvae were removed from the wood and placed into small pre-cleaned plastic containers with forceps that had been previously stored in solvents to prevent cross contamination. Larvae were collected until at least 50 grams of tissue was sampled, and each sample was frozen immediately after collection. Samples were later shipped to a contract laboratory for dioxin analyses. Prior to analysis, larvae were subsampled and identified to the lowest taxonomic level possible to determine the approximate taxonomic composition of the sample.

\section{Streambed-Sediment Sampling and Processing}

In 1989, as part of the MCD Study, streambed-sediment samples were collected from the same eight sites sampled for fish by the same contractor that collected fish that year. In 1992, streambed-sediment samples were collected by the MDEQ, and sampling was expanded to include nine sites on the Leaf River and two sites on the Pascagoula River (table 4). The reach of river sampled for streambed sediments was approximately 105 river miles long.

Table 4. Sites where sediments were sampled for dioxins in the Pascagoula River Basin in 1990 and 1992

\begin{tabular}{lcc}
\multicolumn{1}{c}{ Site number and name } & 1990 & 1992 \\
\hline 0.0 - Leaf River just upstream of the confluence of the Leaf and Bowie Rivers & $\mathrm{X}$ & $\mathrm{X}$ \\
0.5 - Leaf River just below the Hattiesburg wastewater treatment plant outfall & & $\mathrm{X}$ \\
1.0 - Leaf River at the National Guard Landing & $\mathrm{X}$ & $\mathrm{X}$ \\
1.8 - Leaf River just upstream of Highway 29 & & $\mathrm{X}$ \\
2.0 - Leaf River 2 miles downstream of Highway 29 & $\mathrm{X}$ & $\mathrm{X}$ \\
3.0 - Leaf River at Wingate Bridge & $\mathrm{X}$ & $\mathrm{X}$ \\
4.0 - Leaf River at Beaumont & & $\mathrm{X}$ \\
5.0 - Leaf River at McLain & $\mathrm{X}$ & $\mathrm{X}$ \\
6.0 - Leaf River at Merrill & $\mathrm{X}$ & $\mathrm{X}$ \\
7.0 - Pascagoula River at Big Creek & & $\mathrm{X}$ \\
9.0 - Pascagoula River at Black Creek & & $\mathrm{X}$ \\
TA - Tallahala Creek 10 miles upstream of the Leaf River & $\mathrm{X}$ \\
BH - Bogue Homa Creek 10 miles upstream of the Leaf River & $\mathrm{X}$ \\
TH - Thompsons Creek 10 miles upstream of the Leaf River & $\mathrm{X}$ \\
\hline
\end{tabular}


Streambed sediments were collected from a boat using a "clam shell type" grab sampler that had been rinsed with pesticide-grade isopropanol. Sediments in the sampler were examined to ensure that the average particle size was no larger than a fine sand, or 250 micrometers $(\mu \mathrm{m})$, and the grab sampler was checked to ensure that no detritus was trapped in the jaws and no sediments had been lost. If the material was suitable for sampling, the top 1 inch of the sediment was removed and placed in a stainless steel pan that had been rinsed with native water and pesticide-grade isopropanol. Three samples were composited for the MCD Study, but five samples were composited for the 1992 sampling effort. After the samples were composited, the contents were thoroughly mixed. One composite sample was collected from each site for the MCD Study, but replicate composite samples were collected from each site for the 1992 sampling effort. A $250-\mathrm{ml}$ pre-cleaned glass jar was filled from the mixture and was immediately placed on wet ice for transport to the laboratory. Samples were shipped to the contract laboratory for dioxin analysis along with proper chain-of-custody documentation.

\section{Laboratory Analysis}

Isotope dilution high-resolution gas chromatography/high-resolution mass spectrometry was used to perform all dioxin analyses. However, two different methods were used; Method 8290 (U.S. Environmental Protection Agency, 1990a) was used to analyze most samples, but some caddisfly samples were analyzed by Method 1613A (U.S.

Environmental Protection Agency, 1990b). Contract laboratories were selected by the MDEQ that were EPA-certified and had experience analyzing dioxin samples. The minimum acceptable quantification limit for fish tissue, sediment, and caddisfly samples was $1 \mathrm{pg} / \mathrm{g}$; for effluent samples the minimum acceptable quantitative limit was 1 part per quadrillion ( $\mathrm{pg} / \mathrm{l})$. The four sampling media were analyzed for different dioxin congeners at various times during the study (table 5).

\section{Fish Tissue}

For the MCD Study, fish tissue samples were analyzed for 2378 TCDD and 2378 TCDF. This action was based on cost considerations and findings from the National Dioxin Study (U.S. Environmental Protection Agency, 1987) which estimated that approximately 90 percent of dioxin toxicity could be accounted for by 2378 TCDD and 2378 TCDF. However, because 2378 TCDD and $2378 \mathrm{TCDF}$ concentrations were elevated in samples collected for the MCD Study, the MDEQ made a decision to analyze fish tissue samples collected in 1990 for 15 additional dioxin congeners (table 5); thereafter, fish tissue samples were analyzed only for those two congeners.

\section{Effluent}

All effluent samples were analyzed for 2378 TCDD and 2378 TCDF. Because neither 2378 TCDD nor 2378 TCDF were detected in any of the blank samples, results for blank samples are not provided.

\section{Caddisfly}

Prior to October 1993, all caddisfly samples were analyzed only for 2378 TCDD and 2378 TCDF. Samples collected after October 1993 were analyzed for 2378 TCDD and 2378 TCDF and total TCDD and TCDF.

\section{Streambed Sediments}

Streambed-sediment samples collected in 1989 were analyzed for 2378 TCDD and 2378 TCDF. Streambed-sediment samples collected in 1992 were analyzed for 15 additional dioxin congeners (table 5), and total concentrations of TCDD and TCDF, pentachlorodibenzo-p-dioxin (PCCDD), pentachlorodibenzo-p-furan (PCCDF), hexachlorodibenzo-p-dioxin (HXCDD), hexachlorodibenzo-p-furan (HXCDF), heptachlorodibenzo-p-dioxin (HPCDD), and heptachlorodibenzo-p-furan (HPCDF). Sums were computed for total 
Table 5. Analytes for dioxin samples of fish tissue, sediment, mill effluent, and caddisflies collected from the Leaf and Pascagoula Rivers, 1989-97

[F, fish tissue; S, sediment; E, Effluent; C, caddisfly; ---, no data; TOC, total organic carbon; $\mathrm{mg} / \mathrm{kg}$, milligrams per killogram (parts per million)]

\begin{tabular}{|c|c|c|c|c|c|c|c|c|c|}
\hline \multirow[b]{2}{*}{ Congener } & \multicolumn{9}{|c|}{ Year } \\
\hline & 1989 & 1990 & 1991 & 1992 & 1993 & 1994 & 1995 & 1996 & 1997 \\
\hline $\begin{array}{l}\text { 2378TCDF } \\
\text { 2378TCDD }\end{array}$ & $\begin{array}{l}F, S, C \\
F, S, C\end{array}$ & $\begin{array}{l}F, C \\
F, C\end{array}$ & $\begin{array}{l}F, C \\
F, C\end{array}$ & $\begin{array}{l}F, S, C \\
F, S, C\end{array}$ & $\begin{array}{l}F, E, C \\
F, E, C\end{array}$ & $\begin{array}{l}F, E, C \\
F, E, C\end{array}$ & $\begin{array}{l}F, C \\
F, C\end{array}$ & $\begin{array}{l}F, C \\
F, C\end{array}$ & $\begin{array}{l}F, C \\
F, C\end{array}$ \\
\hline 12378PECDF & $S$ & $\mathrm{~F}$ & $\cdots$ & $\mathrm{S}$ & -- & $\cdots$ & -- & -- & --- \\
\hline 23478PECDF & $\mathrm{S}$ & $\mathrm{F}$ & --- & $\mathrm{S}$ & --- & --- & --- & --- & --- \\
\hline 12378PECDD & S & $\mathrm{F}$ & --- & $\mathrm{s}$ & --- & --- & --- & --- & --- \\
\hline $123478 \mathrm{HXCDF}$ & $\mathrm{s}$ & $\mathrm{F}$ & --- & $\mathrm{s}$ & --- & --- & --- & --. & --- \\
\hline $123678 \mathrm{HXCDF}$ & $\mathrm{s}$ & $\mathrm{F}$ & --- & $\mathrm{s}$ & -.- & --- & --- & -..- & --- \\
\hline $234678 \mathrm{HXCDF}$ & $\mathrm{s}$ & $\mathrm{F}$ &.-- & $\mathrm{S}$ & --- & --- & --- & --- & --- \\
\hline $123789 \mathrm{HXCDF}$ & $\mathrm{S}$ & $\mathrm{F}$ & --- & $\mathrm{S}$ & --- & --- & --- & --- & --- \\
\hline $123478 \mathrm{H} \times C D D$ & $S$ & $\mathrm{~F}$ & $\ldots$ & $\mathrm{S}$ & --- & --- & --- & --- & --- \\
\hline $123678 \mathrm{HXCDD}$ & $\mathrm{S}$ & $\mathrm{F}$ & --- & $\mathrm{S}$ & --- & --- & --- & --- & --- \\
\hline $123789 H \times C D D$ & $\mathrm{~S}$ & $\mathrm{~F}$ & --- & $\mathrm{S}$ & --- & -.- & --- & --- & --- \\
\hline 1234678HPCDF & $\mathrm{S}$ & $\mathrm{F}$ & --- & $\mathrm{S}$ & -.- & --- & --- & --- & --- \\
\hline 1234789HPCDF & S & $\mathrm{F}$ & -.- & $\mathrm{S}$ & --- & --. & -.- & --- & --- \\
\hline 1234678HPCDD & $\mathrm{S}$ & $\mathrm{F}$ & --- & $\mathrm{s}$ & --- & --. & --- & --- & --- \\
\hline 12346789OCDF & $\mathrm{S}$ & $\mathrm{F}$ & --- & $\mathrm{S}$ & --- & -.. & --- & --- & --- \\
\hline $123467890 \mathrm{CDD}$ & $\mathrm{S}$ & $\mathrm{F}$ & --- & $\mathrm{S}$ & --- & --- & $\cdots$ & --- & --- \\
\hline TCDF & $\mathrm{s}$ & $\mathrm{F}$ & --- & $\mathrm{S}$ & C & C & C & C & C \\
\hline TCDD & $\mathrm{s}$ & $\mathrm{F}$ & --- & $S$ & C & C & C & C & C \\
\hline PECDF & S & $\mathrm{F}$ & --- & $\mathrm{S}$ & --- & --- & -- & --- & --- \\
\hline PECDD & $\mathrm{S}$ & $\mathrm{F}$ & --- & $\mathrm{S}$ & --- & --- & --- & -- & --- \\
\hline $\mathrm{HXCDF}$ & $\mathrm{S}$ & $\mathrm{F}$ & --- & $\mathrm{S}$ & --- & --- & --- & --- & --- \\
\hline $\mathrm{HXCDD}$ & S & $\mathrm{F}$ & --- & $\mathrm{S}$ & --- & --- & --- & --- & $\ldots$ \\
\hline HPCDF & $\mathrm{S}$ & $\mathrm{F}$ & --- & $\mathrm{S}$ & $\cdots$ & --- & --- & -- & --- \\
\hline HPCDD & $S$ & $\mathrm{~F}$ & -- & $S$ & -- & --- & --- & --- & --- \\
\hline TOC $(\mathrm{mg} / \mathrm{kg})$ & --- & --- & --. & $S$ & --- & --- & --- & -- & --- \\
\hline$\%$ Dry Fraction & -- & --- & $\ldots$ & $\mathrm{S}$ & --- & --. & --- & --- & --- \\
\hline
\end{tabular}

concentrations of TCDD, TCDF, PCCDD, PCCDF, HXCDD, HXCDF, HPCDD, HPCDF, OCDD, and OCDF [or all PCDD and PCDFs (PCDD/Fs)]. A toxicity equivalents concentration (TEC) was calculated by multiplying the concentration of each congener having chlorine atoms located at the $2,3,7,8$ positions by its respective toxicity equivalence factor from table 1 (Barnes and Bellin, 1989). In order to calculate TEC and to obtain a sum of total concentrations for all PCDD/Fs, nondetections (ND) were considered to be zero, and all detection values were considered to be absolute regardless of the detection method.

Streambed-sediment samples collected in 1989 and in 1992 were analyzed for total organic carbon (TOC). The TOC analyses for the samples collected in 1989 were done by the same contract laboratory that performed dioxin analyses. For 1992 streambed-sediment samples, the percentages of the sample that were dry fraction and TOC were determined by the MDEQ laboratory in Pearl, Mississippi.

\section{Quality Assurance}

Although the contract laboratories had extensive quality-assurance protocols, the MDEQ took extra steps to ensure that data used to issue dioxin consumption advisories were of acceptable quality. The quality-assurance process began in the field where all sampling gear and containers were thoroughly cleaned prior to sampling. 
Left-side fillets were submitted to the contract laboratory for analysis, and the right side fillets were archived for future analyses and quality-assurance purposes. This practice proved valuable on a few occasions when a sample was broken, when there was a shipping mistake, or when there was a questionable result.

To maintain consistency throughout the course of the study period, the MDEQ typically relied on one laboratory as the primary contract laboratory, but periodically used two other laboratories for backup and quality-assurance purposes. The MDEQ changed primary laboratories in 1991 due to cost considerations, but conducted rigorous inter-laboratory comparisons before making the change. As a quality-assurance check for fish tissue analyses, two separate inter-laboratory tests were performed among the three laboratories. The results of this exercise indicated that two of the laboratories were providing comparable results, while the third laboratory was consistently reporting lower values. The discrepancy was eventually traced to differences in homogenization procedures at the third laboratory. The third laboratory only analyzed samples collected for the MCD Study and for the inter-laboratory comparison; consequently, the discrepancy presented no substantial problem.

\section{Developing Criteria for Fish- Consumption Advisories}

By mid-1989, it was apparent that 2378 TCDD concentrations in fish from the Leaf River were elevated; however, criteria for issuing dioxin advisories were not established in Mississippi at that time. The only levels of concern for 2378 TCDD in fish tissue were FDA action levels. The FDA suggests limiting consumption when concentrations exceed $25 \mathrm{pg} / \mathrm{g}$, and that no fish be consumed when concentrations exceed $50 \mathrm{pg} / \mathrm{g}$. These levels were established to protect consumers from contaminated products in the market place, but were not considered to be protective of local recreational and subsistence anglers, and populations at high risk (such as pregnant women and young children). As the study progressed, EPA Region IV staff suggested that the MDEQ use a more conservative level of protection than the FDA levels, but they did not recommend actual levels as criteria. Because of the controversy surrounding dioxin's carcinogenicity, toxicity, and possible disruption of reproductive processes, the MDEQ agreed initially that the agency should approach the issue aggressively, and that criteria should be as protective as possible.

Because of public concern about health risks associated with consuming fish from the Leaf River, the MDEQ initially modified existing advisories as soon as data were reviewed from each of the three annual sampling efforts. Old advisory signs were removed and new advisory signs were posted in the advisory areas as fish for the next seasonal sample effort were being collected. In addition to being modified frequently, the advisories lacked consistency because there was no clear guidance or precedent. This led to public confusion, and it became apparent that criteria for issuing advisories were needed. The MDEQ began to review literature so that new criteria for evaluating fish tissue data and issuing consumption advisories could be developed. In November 1990, a multi-agency task force of biologists, engineers, and medical doctors from the MDEQ, the MDWFP, and the Mississippi Department of Health (MDH) was formed to assist with developing the criteria.

By December 1990, the task force had established new criteria for issuing advisories. The new criteria recommended that the MDEQ issue "limit consumption" advisories when 2378 TCDD concentrations reached $5 \mathrm{pg} / \mathrm{g}$, and that "no consumption" advisories be issued when concentrations reached $25 \mathrm{pg} / \mathrm{g}$. These criteria were comparable to criteria already established by other agencies (table 6). "Limit consumption" advisories suggested that the public limit consumption of one or more fish species or size classes to no more than eight 0.25-lb meals per year; "no consumption" advisories suggested that the public not consume any meals from one or more named fish species, or listed size classes. Each time the MDEQ recommended a "no consumption" advisory, the MDWFP issued a ban on commercial fishing. 
The task force also developed general guidance for issuing consumption advisories:

- advisories would be species and size specific when data were available;

- the weighted mean concentration of all fish tissue samples collected for a species in that year would be compared to established criteria;

- the advisory area would include a buffer zone extending one site upstream and downstream of the site where weighted mean concentrations exceeded established criteria;

- the advisory would be reviewed annually after all samples for the year were analyzed and data were evaluated by the task force; and

- advisories would be made public by news releases prepared cooperatively by the public information sections of all agencies forming the task force.
Weighted mean concentrations were calculated for all samples of a fish species collected at a site using the following equation:

$$
\mu=\Sigma X i / \Sigma Y i
$$

where

$\mu \quad$ is the weighted mean concentration;

$\Sigma X \quad$ is the sum of the number of fish in a respective sample (of a species), multiplied by the mean weight of the fish in the sample, multiplied by the dioxin concentration of the sample;

$\Sigma Y \quad$ is the sum of the number of fish in each sample (of a species), multiplied by the mean weight of the fish in each sample; and

$i$ is the number of samples for the species at the site.

If only one fish sample of a species was collected at a site, then laboratory results for that one sample were reported.

Table 6. U.S. Food and Drug Administration action levels for 2,3,7,8 tetracloro-dibenzo-p-dioxin and criteria used by three southeastern States for issuing consumption advisories for fish tissue

\begin{tabular}{|c|c|c|}
\hline Agency & $\begin{array}{l}\text { Concentration } \\
\text { (parts per trillion) }\end{array}$ & Action \\
\hline U.S. Food and Drug Administration' & $\begin{array}{l}25 \\
50\end{array}$ & $\begin{array}{l}\text { Limit consumption } \\
\text { Ban consumption }\end{array}$ \\
\hline Mississippi Department of Environmental Quality² & $\begin{array}{r}5 \\
25\end{array}$ & $\begin{array}{l}\text { Limit consumption } \\
\text { Ban consumption }\end{array}$ \\
\hline $\begin{array}{l}\text { North Carolina Department of Environmental } \\
\text { Management }^{2}\end{array}$ & $\begin{array}{r}3 \\
30\end{array}$ & $\begin{array}{l}\text { Limit consumption } \\
\text { Ban consumption }\end{array}$ \\
\hline $\begin{array}{l}\text { Tennessee Department of Environment and } \\
\text { Conservation }^{2}\end{array}$ & $\begin{array}{r}5 \\
20\end{array}$ & $\begin{array}{l}\text { Limit consumption } \\
\text { Ban consumption }\end{array}$ \\
\hline
\end{tabular}

1 U.S. Food and Drug Administration, 1992

${ }^{2}$ Values confirmed by oral communication with agency, 1990 


\section{RESULTS AND DISCUSSION}

Dioxin results for all fish and caddisfly tissue samples are reported in parts per trillion of 2378 TCDD and 2378 TCDF. Fish samples collected in 1990 confirmed that there was not an appreciable contribution to total PCDD/F concentrations by dioxin congeners other than 2378 TCDD and 2378 TCDF; therefore, to facilitate annual comparisons, only data for 2378 TCDD and 2378 TCDF are reported. Fishtissue data are summarized as weighted means of 2378 TCDD and 2378 TCDF for all samples of a species collected at a site in a given year. Data for individual samples are not provided for two reasons: the large number of fish samples that were collected, and because seasonal variability was not evident for any year or species sampled.

Dioxin results for all sediment samples are reported in parts per trillion for 17 dioxin compounds and for total TCDD, TCDF, PCCDD, PCCDF, HXCDD, HXCDF, HXCDD, and HPCDF. Dioxin results for all effluent samples are reported in parts per quadrillion (pg/l) for 2378 TCDD and $2378 \mathrm{TCDF}$.

\section{Fish Tissue Data}

A list of fish collected, the total number of samples analyzed, the total number of fish collected, the average weight of each fish, and the estimated total weight of all samples are provided for 1989-97 in table 7. For the period of study, 710 samples comprised of almost 2,000 fish with a gross weight slightly less than $7,400 \mathrm{lb}$ were collected. More than 200 samples were analyzed in 1990, but about 70 samples were of individual fish. The greatest weights of fish samples (gross, approximately $1,700 \mathrm{lb}$ ) were collected in 1992 and 1993. The average weight of the fish sampled increased from 1989 to 1994 , but remained stable at about $8 \mathrm{lb}$ from 1994 to 1996 . The average size of the samples decreased to less than $2.5 \mathrm{lb}$ in 1997 as monitoring efforts focused only on channel catfish.

Table 7. Common names of fish species and information for fish samples collected for dioxin analysis from the Leaf and Pascagoula Rivers, 1989-97

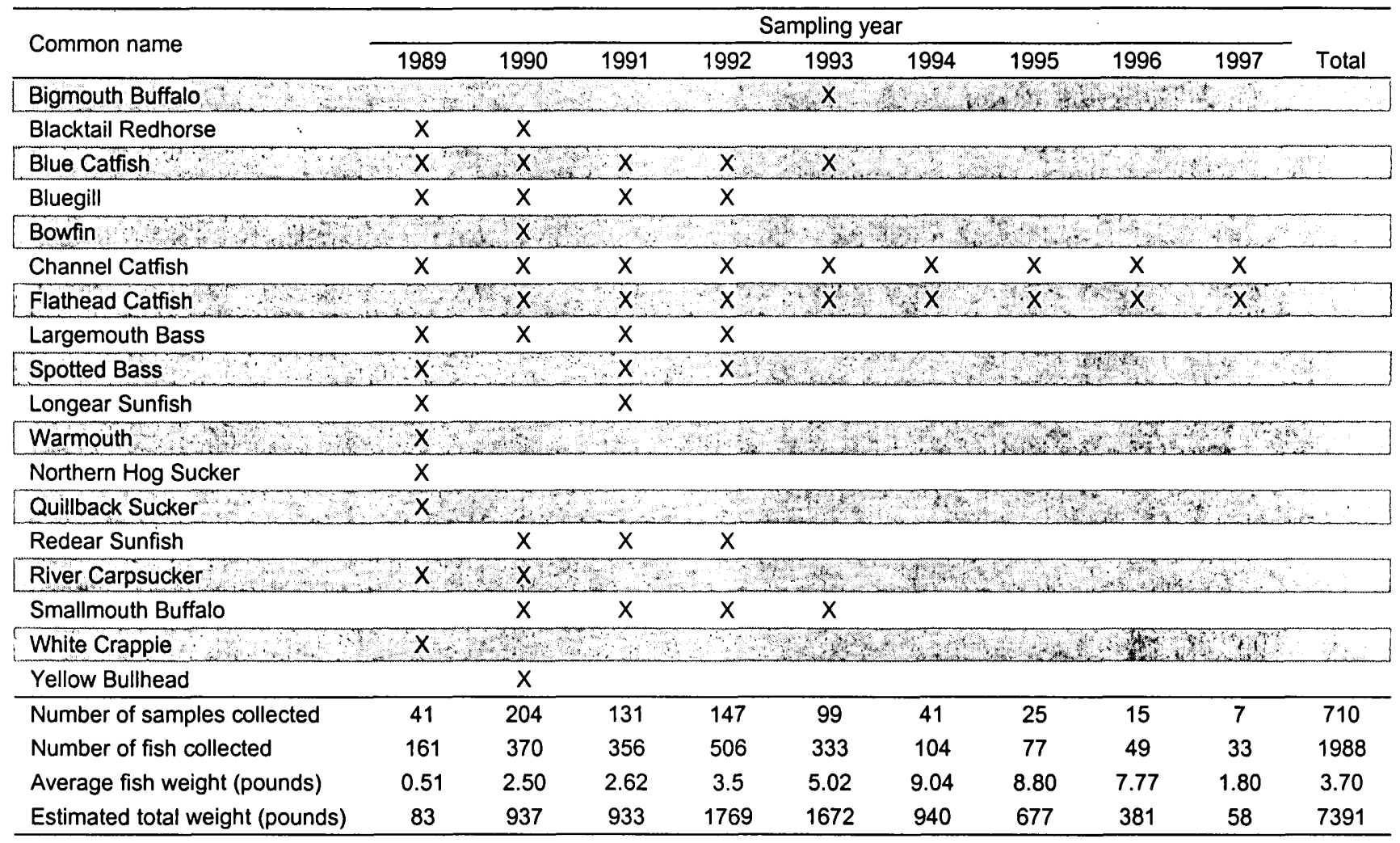


Results for fish samples analyzed for dioxin for 1989-97 are summarized in tables 8-16. The most complete data sets for 2378 TCDD in channel catfish are for sites 2.0, 3.0, and 4.0 for $1989-97$ (fig. 3). The most complete data sets for 2378 TCDD in flathead catfish are for sites 2.0, 4.0, 5.0, and 6.0 for 1990-97 (fig. 4). Annual weighted mean concentrations of 2378 TCDD in flathead and channel catfish were calculated for sites $2.0,4.0,5.0$, and 6.0 for 1990-96 (fig. 5).

Although the average weight of fish samples collected from 1989-92 increased, dioxins in fish tissue decreased (tables 8-11, figs. 3-5). Concentrations for 2378 TCDD were near $25 \mathrm{pg} / \mathrm{g}$ for a channel catfish collected in 1989 and for flathead catfish samples collected in 1990 at site 2.0 just downstream from the mill discharge (tables 8 and 9, figs. 3 and 4). By 1991, weighted means for 2378 TCDD for channel and flathead catfish samples were 3.6 and $7.7 \mathrm{pg} / \mathrm{g}$ (fig. 5), decreases of 85 and 70 percent, respectively, and it became evident that concentrations were higher in flathead catfish than in other species. Weighted mean concentrations of 2378 TCDD in channel and flathead catfish sampled during 1993 were lower at site 2.0 than at sites downstream (table 12)--a condition that, with few exceptions, continued annually through 1997 (tables 13-16).

The most likely cause of the decrease of dioxins in fish tissue was changes made by the mill to the bleaching process. After dioxins were identified in the late 1980's as being associated with bleach-kraft mills, the paper industry began to focus on reducing dioxins being produced during the bleaching process. There were several changes made at the mill that may have contributed to eliminating a major source of 2378 TCDD and 2378 TCDF: reduced use of wastewater for cleaning, a conversion from defoaming agents that contained dioxin precursors, and the addition of a high-pressure diffuser to reduce organic compounds prior to bleaching. However, the general consensus is that the major determining factor which resulted in the virtual elimination of the manufacture of 2378 TCDD at the mill was the discontinued use of chlorine in the bleaching process (Acker Smith, Leaf River Forest Products, written commun., 1998; Phil Bass, MDEQ, oral commun., 1998). Historically, a mixture of
15 percent chlorine dioxide and 85 percent chlorine had been used for the bleaching process, but a gradual conversion was made in the 1980's from that mixture to 100 percent chorine dioxide by June 1990 (Acker Smith, Leaf River Forest Products, oral commun., 1999).

Three factors that may have influenced, or interacted to accelerate, the decrease of 2378 TCDD in fish tissue after the major source was eliminated are flushing of contaminated sediments by streamflow; depuration by aquatic organisms; and a short half-life of the contaminant in fish tissue, sediment, or both. The decrease of 2378 TCDD at site 2.0, before a decrease occurred at downstream sites, indicates that after the major source of 2378 TCDD was eliminated, the sediments may have continued to be a source of 2378 TCDD for a short period; however, as contaminated sediments were flushed from site 2.0 by streamflow, concentrations in fish decreased.

Little is known about depuration rates of 2378 TCDD in fish; however, Kuehle and others (1987) reported that the contaminant was depurated from carp held in uncontaminated aquaria at a rate of 32 to 34 percent after 205 days, and at a rate of 55 percent after 325 days. Data from their study suggest that the chemical reached the first half-life in carp after approximately 325 days. It is not known how this applies to other fish species, but data from this study suggest the half-life in catfish could be similar.

There was concern that the sludge spill in 1992 would cause dioxin concentrations in fish tissue to increase. Although there was no measurable increase in dioxin concentrations in fish tissue after the 1992 sludge spill, a decrease was not evident from 1992 to 1993, as was the case for all other monitoring years (fig. 5). Therefore, it cannot be conclusively shown that dioxin concentrations in fish tissue were not affected by the sludge spill. Dioxin concentrations in fish tissue did continue to decrease after 1993, and by 1996, annual weighted mean concentrations for 2378 TCDD were below a level determined to be background for fish tissue in the United States $(0.56 \mathrm{pg} / \mathrm{g}$, U.S. Environmental Protection Agency, 1992b) for six of the seven catfish samples analyzed (table 15). 
Table 8. Concentrations of 2,3,7,8 tetracloro-dibenzo-p-dioxin (TCDD) and 2,3,7,8 tetraclorodibenzofuran (TCDF) in fish tissue samples from the Leaf River basin for the Mississippi Cooperative Dioxin Study, 1989 [no., number; pg/g, parts per trillion; Min, minimum; Max, maximum; TEC, toxicity equivalence; --, no data; ND, non detect values unavailable]

\begin{tabular}{|c|c|c|c|c|c|c|c|c|}
\hline \multirow[b]{2}{*}{ Site no. ${ }^{a}$} & \multirow[b]{2}{*}{ Common name } & \multirow[b]{2}{*}{$\begin{array}{l}\text { No. } \\
\text { Fish }\end{array}$} & \multicolumn{3}{|c|}{$\begin{array}{c}\text { Weight } \\
\text { (pounds) }\end{array}$} & \multicolumn{3}{|c|}{$\begin{array}{l}\text { Dixoin } \\
(\mathrm{pg} / \mathrm{g})\end{array}$} \\
\hline & & & Min & Max & Mean & TCDD & TCDF & TEC \\
\hline 0.5 & Spotted Bass & 4 & -- & - & 0.6 & 1.6 & 1.2 & 1.7 \\
\hline 0.5 & White Crappie & 1 & -- & -- & 0.4 & 0.3 & ND & 0.3 \\
\hline 0.5 & Longear/Warmouth & 2 & .- & -- & 0.1 & ND & ND & 0.0 \\
\hline 0.5 & River Carpsucker & 6 & -- & - & 0.6 & 6.2 & 4.5 & 6.7 \\
\hline 0.5 & Blacktail Redhorse & 5 & -- & - & 0.6 & 0.5 & ND & 0.5 \\
\hline 0.5 & Channel Catfish & 5 & -- & - & 1.8 & 1.6 & 0.2 & 1.6 \\
\hline 1.3 & Largemouth Bass & 1 & -- & - & 0.2 & ND & ND & 0.0 \\
\hline$\cdot 1.3$ & White Crappie & 1 & -- & - & 0.6 & 0.4 & ND & 0.4 \\
\hline 1.3 & Longear/Bluegill & 6 & - & - & 0.1 & ND & ND & 0.0 \\
\hline 1.3 & River Carpsucker & 5 & -- & - & 0.6 & 5.5 & 4.1 & 5.9 \\
\hline 1.3 & Blacktail Redhorse & 5 & .- & -- & 0.9 & 0.8 & ND & 0.8 \\
\hline 1.3 & Channel Catfish & 4 & - & - & 1.0 & 1.5 & ND & 1.5 \\
\hline 2.0 & Largemouth/Sp. Bass & 3 & -- & -- & 0.1 & 5.7 & 1.6 & 5.9 \\
\hline 2.0 & White Crappie & 5 & - & - & 0.1 & 2.0 & 1.0 & 2.1 \\
\hline 2.0 & Bluegill & 3 & -- & - & 0.1 & 0.4 & 0.4 & 0.4 \\
\hline 2.0 & River Carpsucker & 5 & -- & - & 0.3 & 3.5 & 2.8 & 3.8 \\
\hline 2.0 & Blacktail Redhorse & 5 & -- & -- & 0.5 & 3.8 & 2.7 & 4.1 \\
\hline 2.0 & Channel Catfish & 5 & -- & - & 1.9 & 24.0 & 0.4 & 24.0 \\
\hline 2.0 & Blue Catfish & 2 & - & -- & 1.4 & 7.0 & ND & 7.0 \\
\hline 3.0 & Spotted Bass & 4 & - & -- & 0.3 & 5.5 & 2.1 & 5.7 \\
\hline 3.0 & White Crappie & 3 & -- & -- & 0.3 & 1.7 & 1.1 & 1.8 \\
\hline 3.0 & Longear/Bluegill & 6 & -- & -- & 0.1 & 1.4 & ND & 1.4 \\
\hline 3.0 & River Carpsucker & 6 & -. & -- & 0.4 & 7.8 & 8.6 & 8.7 \\
\hline 3.0 & Blacktail Redhorse & 6 & -- & -- & 0.4 & 2.6 & 2.0 & 2.8 \\
\hline 3.0 & Channel Catfish & 5 & -- & -- & 1.0 & 16.0 & 0.3 & 16.0 \\
\hline 5.0 & Spotted Bass & 4 & -- & -- & 0.2 & 1.5 & 1.2 & 1.6 \\
\hline 5.0 & Longear/Bluegill & 5 & -- & -- & 0.1 & ND & ND & 0.0 \\
\hline 5.0 & River Carpsucker & 5 & - & - & 0.8 & 8.0 & 6.0 & 8.6 \\
\hline 5.0 & Blacktail Redhorse & 3 & -- & -- & 0.3 & 2.8 & 2.1 & 3.0 \\
\hline TA & Spotted Bass & 3 & - & - & 0.4 & 0.4 & ND & 0.4 \\
\hline TA & Largemouth Bass & 4 & -- & - & 0.4 & ND & ND & 0.0 \\
\hline TA & Longear Sunfish & 5 & -- & - & 0.1 & 0.2 & 0.0 & 0.2 \\
\hline $\mathrm{TA}$ & Blacktail Redhorse & 5 & - & -- & 0.6 & ND & ND & 0.0 \\
\hline $\mathrm{BH}$ & Spotted Bass & 4 & - & -- & 0.3 & ND & ND & 0.0 \\
\hline $\mathrm{BH}$ & Longear Sunfish & 5 & -- & -- & 0.2 & 1.3 & 0.6 & 1.4 \\
\hline $\mathrm{BH}$ & Quillback Sucker & 2 & -- & -- & 1.1 & 13.0 & 6.3 & 13.6 \\
\hline $\mathrm{BH}$ & Blacktail Redhorse & 2 & -- & - & 0.4 & ND & ND & 0.0 \\
\hline TH & Spotted Bass & 1 & -- & - & 0.4 & 0.5 & 0.4 & 0.5 \\
\hline TH & Longear Sunfish & 5 & -- & -- & 0.1 & 0.7 & 0.3 & 0.7 \\
\hline TH & Northern Hog Sucker & 2 & -- & -- & 0.7 & 0.5 & 0.4 & 0.6 \\
\hline TH & Blacktail Redhorse & 3 & .- & -- & 0.4 & 0.3 & 0.3 & 0.3 \\
\hline
\end{tabular}

a 0.5 - Leaf River just below Hattiesburg wastewater treatment plant outfall

1.3 - Leaf River 10 miles above mill discharge

2.0 - Leaf River 2 miles downstream of Highway 29

3.0 - Leaf River at Wingate Bridge

5.0 - Leaf River near McLain

TA - Tallahala Creek 10 miles upstream from Leaf River

BH - Bogue Homa Creek 10 miles upstream from Leaf River

TH - Thompsons Creek 10 miles upstream from Leaf River 
Table 9. Weighted mean concentrations of 2,3,7,8 tetracloro-dibenzo-p-dioxin (TCDD) and 2,3,7,8 tetraclorodibenzofuran (TCDF) in fish tissue samples from the Leaf and Pascagoula Rivers, Mississippi, 1990 [no., number; pg/g picograms per gram (parts per trillion); Min, minimum; Max, maximum; TEC, toxicity equivalence; ND, non detect values unavailable]

\begin{tabular}{|c|c|c|c|c|c|c|c|c|}
\hline \multirow{2}{*}{ Site number and name } & \multirow[t]{2}{*}{ Common name } & \multirow{2}{*}{$\begin{array}{l}\text { No. } \\
\text { fish }\end{array}$} & \multicolumn{3}{|c|}{$\begin{array}{c}\text { Weight } \\
\text { (pounds) }\end{array}$} & \multicolumn{3}{|c|}{$\begin{array}{l}\text { Dioxin } \\
(\mathrm{pg} / \mathrm{g})\end{array}$} \\
\hline & & & Min & Max & Mean & TCDD & TCDF & TEC \\
\hline $\begin{array}{l}\text { 1.0 - Leaf River at National Guard } \\
\text { Landing }\end{array}$ & $\begin{array}{l}\text { Channel Catfish } \\
\text { Blue Catfish } \\
\text { Flathead Catfish } \\
\text { Carpsucker } \\
\text { Largemouth Bass } \\
\text { Bluegill }\end{array}$ & $\begin{array}{l}17 \\
8 \\
6 \\
1^{\mathrm{a}} \\
5^{\mathrm{a}} \\
5^{\mathrm{a}}\end{array}$ & $\begin{array}{l}0.2 \\
3.7 \\
1.6 \\
0.9 \\
1.5 \\
0.3\end{array}$ & $\begin{array}{r}3.2 \\
21.6 \\
10.0 \\
0.9 \\
5.2 \\
0.3\end{array}$ & $\begin{array}{l}1.4 \\
9.5 \\
5.5 \\
0.9 \\
2.2 \\
0.3\end{array}$ & $\begin{array}{l}0.4 \\
5.4 \\
1.9 \\
\text { ND } \\
\text { ND } \\
\text { ND }\end{array}$ & $\begin{array}{l}\text { ND } \\
0.3 \\
0.2 \\
\text { ND } \\
0.1 \\
0.2\end{array}$ & $\begin{array}{l}0.4 \\
5.5 \\
1.9 \\
0.0 \\
0.0 \\
0.0\end{array}$ \\
\hline $\begin{array}{c}2.0 \text { - Leaf River } 2 \text { miles downstream of } \\
\text { Highway } 29\end{array}$ & $\begin{array}{l}\text { Channel Catfish } \\
\text { Blue Catfish } \\
\text { Flathead Catfish } \\
\text { Largemouth Bass }\end{array}$ & $\begin{array}{r}31 \\
7 \\
17 \\
8\end{array}$ & $\begin{array}{l}0.2 \\
0.3 \\
1.3 \\
1.2\end{array}$ & $\begin{array}{c}3.5 \\
11.9 \\
6.1 \\
1.2\end{array}$ & $\begin{array}{l}1.7 \\
5.8 \\
3.8 \\
1.2\end{array}$ & $\begin{array}{r}8.1 \\
9.8 \\
25.2 \\
1.4\end{array}$ & $\begin{array}{l}0.2 \\
0.4 \\
0.6 \\
0.5\end{array}$ & $\begin{array}{r}8.1 \\
9.8 \\
25.3 \\
1.5\end{array}$ \\
\hline 3.0 - Leaf River at Wingate Road Bridge & $\begin{array}{l}\text { Channel Catfish } \\
\text { Blue Catfish } \\
\text { Flathead Catfish } \\
\text { Bluegill } \\
\text { Largemouth Bass }\end{array}$ & $\begin{array}{c}28 \\
5^{a} \\
13 \\
3^{a} \\
8\end{array}$ & $\begin{array}{l}0.2 \\
0.3 \\
1.3 \\
0.4 \\
1.0\end{array}$ & $\begin{array}{r}2.5 \\
9.4 \\
11.3 \\
0.4 \\
2.0\end{array}$ & $\begin{array}{l}1.3 \\
6.1 \\
4.8 \\
0.4 \\
1.4\end{array}$ & $\begin{array}{r}4.1 \\
8.7 \\
12.2 \\
0.8 \\
1.1\end{array}$ & $\begin{array}{l}0.1 \\
0.3 \\
0.4 \\
0.1 \\
0.5\end{array}$ & $\begin{array}{r}4.1 \\
8.8 \\
12.2 \\
0.8 \\
1.1\end{array}$ \\
\hline 4.0- Leaf River at Beaumont & $\begin{array}{l}\text { Channel Catfish } \\
\text { Blue Catfish } \\
\text { Flathead Catfish } \\
\text { Blacktail Redhorse } \\
\text { Largemouth Bass } \\
\text { Bluegill }\end{array}$ & $\begin{array}{c}20 \\
1^{\mathrm{a}} \\
10^{\mathrm{a}} \\
1^{\mathrm{a}} \\
4^{\mathrm{a}} \\
4^{\mathrm{a}}\end{array}$ & $\begin{array}{l}0.6 \\
0.4 \\
1.3 \\
0.8 \\
1.2 \\
0.4\end{array}$ & $\begin{array}{l}3.3 \\
0.4 \\
7.7 \\
0.8 \\
1.2 \\
0.4\end{array}$ & $\begin{array}{l}1.4 \\
0.4 \\
3.5 \\
0.8 \\
1.2 \\
0.4\end{array}$ & $\begin{array}{l}6.2 \\
2.8 \\
2.6 \\
\text { ND } \\
1.9 \\
0.9\end{array}$ & $\begin{array}{l}0.2 \\
\text { ND } \\
0.3 \\
\text { ND } \\
0.7 \\
0.7\end{array}$ & $\begin{array}{l}6.2 \\
2.8 \\
2.7 \\
0.0 \\
2.0 \\
0.9\end{array}$ \\
\hline 5.0 - Leaf River at McLain & $\begin{array}{l}\text { Channel Catfish } \\
\text { Blue Catfish } \\
\text { Flathead Catfish } \\
\text { Yellow Bullhead } \\
\text { Carpsucker } \\
\text { Smallmouth Buffalo } \\
\text { Redear Sunfish } \\
\text { Largemouth Bass }\end{array}$ & $\begin{array}{c}12 \\
9 \\
10 \\
2^{\mathrm{a}} \\
1^{\mathrm{a}} \\
1^{\mathrm{a}} \\
5^{\mathrm{a}} \\
2^{\mathrm{a}}\end{array}$ & $\begin{array}{r}13.2 \\
0.3 \\
1.9 \\
0.4 \\
1.6 \\
16.2 \\
0.3 \\
1.4\end{array}$ & $\begin{array}{r}18.2 \\
10.8 \\
4.2 \\
0.8 \\
1.6 \\
16.2 \\
0.3 \\
1.4\end{array}$ & $\begin{array}{l}1.6 \\
4.0 \\
2.7 \\
0.6 \\
1.6 \\
0.3 \\
0.3 \\
1.4\end{array}$ & $\begin{array}{l}3.9 \\
7.7 \\
2.8 \\
\text { ND } \\
\text { ND } \\
4.0 \\
\text { ND } \\
\text { ND }\end{array}$ & $\begin{array}{r}0.5 \\
0.6 \\
0.1 \\
\text { ND } \\
4.1 \\
15.6 \\
0.8 \\
\text { ND }\end{array}$ & $\begin{array}{l}3.9 \\
7.8 \\
2.8 \\
0.0 \\
0.4 \\
5.6 \\
0.1 \\
0.0\end{array}$ \\
\hline 6.0 - Leaf River at Merrill & $\begin{array}{l}\text { Channel Catfish } \\
\text { Blue Catfish } \\
\text { Flathead Catfish } \\
\text { Blacktail Redhorse } \\
\text { Bluegill } \\
\text { Largemouth Bass }\end{array}$ & $\begin{array}{c}18 \\
4^{\mathrm{a}} \\
18 \\
1^{\mathrm{a}} \\
6^{\mathrm{a}} \\
5^{\mathrm{a}}\end{array}$ & $\begin{array}{l}0.4 \\
0.3 \\
1.5 \\
0.5 \\
0.2 \\
1.2\end{array}$ & $\begin{array}{r}1.4 \\
8.8 \\
12.7 \\
0.5 \\
0.2 \\
1.2\end{array}$ & $\begin{array}{l}0.8 \\
3.0 \\
3.4 \\
0.5 \\
0.2 \\
1.2\end{array}$ & $\begin{array}{r}1.6 \\
3.5 \\
13.6 \\
1.0 \\
0.6 \\
1.0\end{array}$ & $\begin{array}{l}0.3 \\
0.3 \\
1.0 \\
\text { ND } \\
0.9 \\
0.8\end{array}$ & $\begin{array}{r}1.6 \\
3.5 \\
13.7 \\
1.0 \\
0.7 \\
1.1\end{array}$ \\
\hline 7.0 - Pascagoula River at Big Creek & $\begin{array}{l}\text { Blue Catfish } \\
\text { Channel Catfish } \\
\text { Flathead Catfish }\end{array}$ & $\begin{array}{c}5^{a} \\
3^{a} \\
12\end{array}$ & $\begin{array}{l}7.5 \\
1.0 \\
1.2\end{array}$ & $\begin{array}{l}7.5 \\
1.0 \\
5.5\end{array}$ & $\begin{array}{l}7.5 \\
1.0 \\
2.8\end{array}$ & $\begin{array}{l}6.0 \\
0.8 \\
1.9\end{array}$ & $\begin{array}{l}1.0 \\
0.3 \\
0.7\end{array}$ & $\begin{array}{l}6.1 \\
0.8 \\
2.0\end{array}$ \\
\hline 8.0 - Pascagoula River at Cedar Creek & $\begin{array}{l}\text { Channel Catfish } \\
\text { Sunfish Sp. } \\
\text { Largemouth Bass } \\
\text { Flathead Catfish }\end{array}$ & $\begin{array}{l}3^{\mathrm{a}} \\
5^{\mathrm{a}} \\
1^{\mathrm{a}} \\
3^{\mathrm{a}}\end{array}$ & $\begin{array}{l}1.1 \\
0.2 \\
1.1 \\
2.2\end{array}$ & $\begin{array}{l}3.5 \\
0.2 \\
1.1 \\
2.2\end{array}$ & $\begin{array}{l}1.9 \\
0.2 \\
1.1 \\
2.2\end{array}$ & $\begin{array}{l}2.7 \\
0.8 \\
1.5 \\
2.0\end{array}$ & $\begin{array}{l}0.6 \\
1.1 \\
1.0 \\
0.5\end{array}$ & $\begin{array}{l}2.7 \\
0.9 \\
1.6 \\
2.0\end{array}$ \\
\hline 9.0 - Pascagoula River at Black Creek & $\begin{array}{l}\text { Channel Catfish } \\
\text { Flathead Catfish }\end{array}$ & $4^{\mathrm{a}}$ & $\begin{array}{l}1.3 \\
0.7\end{array}$ & $\begin{array}{r}1.3 \\
17.2\end{array}$ & $\begin{array}{l}1.3 \\
5.1\end{array}$ & $\begin{array}{l}1.3 \\
1.8\end{array}$ & $\begin{array}{l}0.5 \\
0.5\end{array}$ & $\begin{array}{l}1.3 \\
1.8\end{array}$ \\
\hline OX1 - Meyers' Oxbow & $\begin{array}{l}\text { Bowfin } \\
\text { Largemouth Bass } \\
\text { Channel Catfish }\end{array}$ & $\begin{array}{l}4^{a} \\
5^{a} \\
5^{a}\end{array}$ & $\begin{array}{l}3.2 \\
0.4 \\
0.4\end{array}$ & $\begin{array}{l}3.2 \\
0.4 \\
0.4\end{array}$ & $\begin{array}{l}3.2 \\
0.4 \\
0.4\end{array}$ & $\begin{array}{l}\text { ND } \\
\text { ND } \\
\text { ND }\end{array}$ & $\begin{array}{l}0.2 \\
0.2 \\
\text { ND }\end{array}$ & $\begin{array}{l}0.0 \\
0.0 \\
0.0\end{array}$ \\
\hline OX2 - Hintons' Oxbow & $\begin{array}{l}\text { Bowfin } \\
\text { Largemouth Bass } \\
\text { Brown Bullhead }\end{array}$ & $\begin{array}{l}2^{a} \\
5^{a} \\
1^{a}\end{array}$ & $\begin{array}{l}6.8 \\
0.9 \\
0.4\end{array}$ & $\begin{array}{l}6.8 \\
0.9 \\
0.4 \\
\end{array}$ & $\begin{array}{l}6.8 \\
0.9 \\
0.4\end{array}$ & $\begin{array}{l}\text { ND } \\
\text { ND } \\
\text { ND }\end{array}$ & $\begin{array}{l}0.4 \\
0.1 \\
\text { ND }\end{array}$ & $\begin{array}{l}0.0 \\
0.0 \\
0.0\end{array}$ \\
\hline
\end{tabular}

a Actual (rather than weighted mean) dioxin concentrations are shown for species having 5 or fewer fish sampled. 
Table 10. Weighted mean concentrations of 2,3,7,8 tetracloro-dibenzo-p-dioxin (TCDD) and $2,3,7,8$ tetraclorodibenzofuran (TCDF) in fish tissue samples from the Leaf and Pascagoula Rivers, Mississippi, 1991

[no., number; pg/g, picograms per gram (parts per trillion); Min, minimum; Max, maximum; TEC, toxicity equivalence; $<$, nondetection, reported as less than value]

\begin{tabular}{|c|c|c|c|c|c|c|c|c|}
\hline \multirow{2}{*}{$\begin{array}{l}\text { Site } \\
\text { no. }\end{array}$} & \multirow{2}{*}{ Common name } & \multirow{2}{*}{$\begin{array}{l}\text { No. } \\
\text { fish }\end{array}$} & \multicolumn{3}{|c|}{$\begin{array}{l}\text { Weight } \\
\text { (pounds) }\end{array}$} & \multicolumn{3}{|c|}{$\begin{array}{l}\text { Dioxin } \\
\text { (pg/g) }\end{array}$} \\
\hline & & & Min & $\operatorname{Max}$ & Mean & TCDD & TCDF & TEC \\
\hline \multirow[t]{3}{*}{1.0} & Blue Catfish & $2^{b}$ & 2.0 & 2.6 & 2.3 & 1.2 & $<0.1$ & 1.2 \\
\hline & Channel Catfish & 22 & 0.4 & 2.9 & 1.2 & 0.7 & 0.0 & 0.7 \\
\hline & Flathead Catfish & 24 & 2.5 & 27.2 & 6.0 & 3.5 & 0.0 & 3.5 \\
\hline \multirow[t]{5}{*}{2.0} & Blue Catfish & 10 & 1.1 & 20.2 & 7.0 & 4.1 & 0.3 & 4.2 \\
\hline & Channel Catfish & 29 & 0.3 & 2.2 & 1.0 & 3.6 & 0.1 & 3.6 \\
\hline & Flathead Catfish & 17 & 1.5 & 12.6 & 4.9 & 7.7 & 0.1 & 7.7 \\
\hline & Spotted Bass & $3^{b}$ & 0.5 & 2.0 & 1.1 & 0.1 & 0.1 & 0.1 \\
\hline & Bluegill & $4^{b}$ & 0.2 & 0.2 & 0.2 & 0.2 & 0.1 & 0.2 \\
\hline \multirow[t]{6}{*}{4.0} & Blue Catfish & $3^{b}$ & 1.6 & 2.7 & 2.2 & 1.6 & 0.0 & 1.6 \\
\hline & Channel Catfish & 26 & 0.5 & 3.3 & 1.4 & 4.5 & 0.2 & 4.5 \\
\hline & Flathead Catfish & 16 & 1.9 & 7.0 & 3.9 & 7.4 & 0.3 & 7.4 \\
\hline & Largemouth Bass & $5^{b}$ & 1.5 & 4.0 & 2.4 & 1.2 & 0.3 & 1.2 \\
\hline & Longear Sunfish & $5^{b}$ & 0.1 & 0.2 & 0.1 & 0.2 & 0.1 & 0.2 \\
\hline & Smallmouth Buffalo & $1^{b}$ & 3.5 & 3.5 & 3.5 & 1.0 & 2.8 & 1.3 \\
\hline \multirow[t]{6}{*}{5.0} & Blue Catfish & 9 & 0.6 & 11.4 & 4.4 & 10.5 & 0.4 & 10.6 \\
\hline & Channel Catfish & 24 & 0.6 & 2.3 & 1.2 & 2.4 & 0.3 & 2.4 \\
\hline & Flathead Catfish & 13 & 1.2 & 11.9 & 4.2 & 6.7 & 0.2 & 6.7 \\
\hline & Largemouth Bass & 6 & 0.5 & 3.2 & 1.3 & 2.0 & 0.4 & 2.1 \\
\hline & Bluegill & $5^{b}$ & 0.1 & 0.3 & 0.2 & 0.2 & 0.1 & 0.2 \\
\hline & Smallmouth Buffalo & $2^{b}$ & 2.4 & 2.9 & 2.7 & 1.4 & 1.2 & 1.5 \\
\hline \multirow[t]{5}{*}{6.0} & Blue Catfish & 12 & 0.5 & 20.5 & 3.9 & 4.9 & 0.4 & 5.0 \\
\hline & Channel Catfish & 28 & 0.5 & 2.7 & 1.0 & 1.7 & 0.1 & 1.7 \\
\hline & Flathead Catfish & 10 & 1.1 & 13.5 & 5.1 & 10.4 & 0.3 & 10.4 \\
\hline & Spotted Bass & 7 & 0.9 & 2.5 & 1.3 & 0.7 & 0.3 & 0.7 \\
\hline & Bluegill & $5^{b}$ & 0.1 & 0.4 & 0.2 & $<0.3$ & 0.1 & 0.0 \\
\hline \multirow[t]{5}{*}{7.0} & Blue Catfish & 8 & 0.7 & 11.7 & 3.0 & 3.2 & 0.4 & 3.2 \\
\hline & Channel Catfish & 25 & 0.5 & 2.8 & 1.3 & 3.2 & 0.3 & 3.2 \\
\hline & Flathead Catfish & 14 & 2.1 & 18.1 & 6.6 & 5.2 & 0.3 & 5.2 \\
\hline & Largemouth Bass & $4^{b}$ & 1.1 & 2.7 & 1.9 & 0.3 & $<0.1$ & 0.3 \\
\hline & Bluegill & $5^{b}$ & 0.1 & 0.3 & 0.2 & 0.2 & 0.1 & 0.2 \\
\hline \multirow[t]{2}{*}{ OX1 } & Channel Catfish & $2^{b}$ & 2.6 & 3.3 & 2.9 & 1.5 & 0.1 & 1.5 \\
\hline & Largemouth Bass & $1^{0}$ & 5.0 & 5.0 & 5.0 & 0.3 & 0.1 & 0.3 \\
\hline \multirow[t]{3}{*}{$0 \times 2$} & Channel Catfish & $2^{b}$ & 0.9 & 0.9 & 0.9 & 0.3 & $<0.1$ & 0.3 \\
\hline & Largemouth Bass/Spotted Bass & $2^{b}$ & 1.3 & 4.3 & 2.8 & $<0.2$ & $<0.2$ & 0.0 \\
\hline & Redear Sunfish & $5^{\mathrm{b}}$ & 0.3 & 0.4 & 0.3 & 0.1 & 0.1 & 0.1 \\
\hline \multicolumn{4}{|c|}{$\begin{array}{l}\text { 1.0 - Leaf River at National Guard Landing } \\
2.0 \text { - Leaf River } 2 \text { miles downstream of Highway } 29 \\
4.0 \text { - Leaf River at Beaumont } \\
5.0 \text { - Leaf River at McLain }\end{array}$} & \multicolumn{5}{|c|}{$\begin{array}{l}6.0 \text { - Leaf River at Merrill } \\
7.0 \text { - Pascagoula River at Big Creek } \\
\text { OX1 - Meyers' Oxbow } \\
\text { OX2 - Hintons' Oxbow }\end{array}$} \\
\hline
\end{tabular}


Table 11. Weighted mean concentrations of 2,3,7,8 tetracloro-dibenzo-p-dioxin (TCDD) and 2,3,7,8 tetraclorodibenzofuran (TCDF) in fish tissue samples from the Leaf and Pascagoula Rivers, Mississippi, 1992 [no., number; Min, minimum; Max, maximum; pg/g, picograms per gram (parts per trillion) TEC, toxicity equivalence]

\begin{tabular}{|c|c|c|c|c|c|c|c|c|}
\hline \multirow{2}{*}{$\begin{array}{l}\text { Site } \\
\text { no. }{ }^{a}\end{array}$} & \multirow{2}{*}{ Common name } & \multirow{2}{*}{$\begin{array}{l}\text { No. } \\
\text { fish }\end{array}$} & \multicolumn{3}{|c|}{$\begin{array}{l}\text { Weight } \\
\text { (pounds) }\end{array}$} & \multicolumn{3}{|c|}{$\begin{array}{l}\text { Dioxin } \\
\text { (pg/g) }\end{array}$} \\
\hline & & & Min & Max & Mean & TCDD & TCDF & TEC \\
\hline 0.5 & $\begin{array}{l}\text { Channel Catfish } \\
\text { Flathead Catfish } \\
\text { Smallmouth Buffalo } \\
\text { Bluegill } \\
\text { Largemouth Bass }\end{array}$ & $\begin{array}{l}20 \\
22 \\
3^{b} \\
5^{b} \\
5^{b}\end{array}$ & $\begin{array}{l}0.5 \\
1.2 \\
8.4 \\
0.2 \\
0.7\end{array}$ & $\begin{array}{r}2.4 \\
19.8 \\
11.1 \\
0.5 \\
3.3\end{array}$ & $\begin{array}{l}1.0 \\
5.8 \\
9.7 \\
0.3 \\
1.5\end{array}$ & $\begin{array}{l}0.4 \\
1.9 \\
0.8 \\
0.0 \\
0.0\end{array}$ & $\begin{array}{l}0.0 \\
0.1 \\
1.3 \\
0.0 \\
0.0\end{array}$ & $\begin{array}{l}0.4 \\
1.9 \\
0.9 \\
0.0 \\
0.0\end{array}$ \\
\hline 1.0 & $\begin{array}{l}\text { Blue Catfish } \\
\text { Channel Catfish } \\
\text { Flathead Catfish } \\
\text { Smallmouth Buffalo } \\
\text { Bluegill } \\
\text { Largemouth Bass/Spotted Bass }\end{array}$ & $\begin{array}{c}1^{\mathrm{b}} \\
25 \\
21 \\
3^{\mathrm{b}} \\
5^{\mathrm{b}} \\
3^{\mathrm{b}}\end{array}$ & $\begin{array}{l}8.8 \\
0.4 \\
1.3 \\
6.0 \\
0.3 \\
1.9\end{array}$ & $\begin{array}{r}8.8 \\
3.4 \\
17.4 \\
10.2 \\
0.5 \\
3.0\end{array}$ & $\begin{array}{l}8.8 \\
1.1 \\
5.9 \\
7.9 \\
0.3 \\
2.6\end{array}$ & $\begin{array}{l}1.1 \\
0.2 \\
2.0 \\
2.0 \\
0.0 \\
0.2\end{array}$ & $\begin{array}{l}1.2 \\
0.0 \\
0.1 \\
1.1 \\
0.0 \\
0.1\end{array}$ & $\begin{array}{l}1.2 \\
0.2 \\
2.0 \\
2.1 \\
0.0 \\
0.3\end{array}$ \\
\hline 2.0 & $\begin{array}{l}\text { Blue Catfish } \\
\text { Channel Catfish } \\
\text { Flathead Catfish } \\
\text { Smallmouth Buffalo } \\
\text { Bluegill } \\
\text { Largemouth Bass/Spotted Bass }\end{array}$ & $\begin{array}{l}10 \\
18 \\
25 \\
4^{b} \\
4^{b} \\
5^{b}\end{array}$ & $\begin{array}{l}3.8 \\
0.6 \\
1.9 \\
8.4 \\
0.2 \\
0.6\end{array}$ & $\begin{array}{r}20.6 \\
3.1 \\
20.4 \\
16.4 \\
0.4 \\
2.1\end{array}$ & $\begin{array}{r}9.8 \\
1.4 \\
5.9 \\
11.2 \\
0.3 \\
1.3\end{array}$ & $\begin{array}{l}4.1 \\
1.1 \\
5.4 \\
3.0 \\
0.4 \\
0.2\end{array}$ & $\begin{array}{l}0.2 \\
0.1 \\
0.2 \\
0.7 \\
0.4 \\
0.2\end{array}$ & $\begin{array}{l}4.1 \\
1.1 \\
5.4 \\
3.1 \\
0.4 \\
0.2\end{array}$ \\
\hline 4.0 & $\begin{array}{l}\text { Blue Catfish } \\
\text { Channel Catfish } \\
\text { Flathead Catfish } \\
\text { Smallmouth Buffalo } \\
\text { Bluegill } \\
\text { Largemouth Bass }\end{array}$ & $\begin{array}{c}6 \\
23 \\
26 \\
3^{b} \\
5^{b} \\
5^{b}\end{array}$ & $\begin{array}{l}1.3 \\
0.6 \\
1.6 \\
3.5 \\
0.2 \\
0.5\end{array}$ & $\begin{array}{r}6.4 \\
5.0 \\
22.8 \\
8.8 \\
0.4 \\
1.3\end{array}$ & $\begin{array}{l}4.4 \\
1.9 \\
5.4 \\
6.4 \\
0.3 \\
0.9\end{array}$ & $\begin{array}{l}2.8 \\
2.0 \\
5.6 \\
8.0 \\
0.0 \\
0.0\end{array}$ & $\begin{array}{l}0.6 \\
0.4 \\
0.2 \\
6.6 \\
0.0 \\
0.0\end{array}$ & $\begin{array}{l}2.9 \\
2.0 \\
5.7 \\
8.6 \\
0.0 \\
0.0\end{array}$ \\
\hline 5.0 & $\begin{array}{l}\text { Blue Catfish } \\
\text { Channel Catfish } \\
\text { Flathead Catfish } \\
\text { Smallmouth Buffalo } \\
\text { Redear } \\
\text { Largemouth Bass }\end{array}$ & $\begin{array}{l}3^{b} \\
20 \\
29 \\
1^{b} \\
3^{b} \\
5^{b}\end{array}$ & $\begin{array}{l}0.9 \\
0.6 \\
1.2 \\
7.7 \\
0.3 \\
0.5\end{array}$ & $\begin{array}{r}3.9 \\
3.1 \\
17.7 \\
7.7 \\
0.6 \\
3.4\end{array}$ & $\begin{array}{l}2.2 \\
1.4 \\
6.9 \\
7.7 \\
0.4 \\
1.2\end{array}$ & $\begin{array}{l}1.0 \\
1.7 \\
4.3 \\
3.7 \\
0.2 \\
1.0\end{array}$ & $\begin{array}{l}0.1 \\
0.3 \\
0.3 \\
4.8 \\
0.3 \\
0.2\end{array}$ & $\begin{array}{l}1.0 \\
1.7 \\
4.3 \\
4.2 \\
0.2 \\
1.0\end{array}$ \\
\hline 6.0 & $\begin{array}{l}\text { Bluecatfish } \\
\text { Channel Catfish } \\
\text { Flathead Catfish } \\
\text { Bluegill } \\
\text { Largemouth Bass/Spotted Bass }\end{array}$ & $\begin{array}{c}5^{b} \\
18 \\
29 \\
5^{b} \\
5^{b}\end{array}$ & $\begin{array}{l}1.3 \\
0.4 \\
1.0 \\
0.1 \\
0.4\end{array}$ & $\begin{array}{r}6.2 \\
1.9 \\
14.1 \\
0.4 \\
0.8\end{array}$ & $\begin{array}{l}3.4 \\
0.7 \\
5.3 \\
0.2 \\
0.6\end{array}$ & $\begin{array}{l}1.2 \\
1.4 \\
2.4 \\
0.0 \\
0.0\end{array}$ & $\begin{array}{l}0.2 \\
0.0 \\
0.3 \\
0.0 \\
0.0\end{array}$ & $\begin{array}{l}1.3 \\
1.4 \\
2.4 \\
0.0 \\
0.0\end{array}$ \\
\hline 7.0 & $\begin{array}{l}\text { Blue Catfish } \\
\text { Channel Catfish } \\
\text { Flathead Catfish } \\
\text { Smallmouth Buffalo } \\
\text { Redear } \\
\text { Largemouth Bass }\end{array}$ & $\begin{array}{c}11 \\
16 \\
25 \\
1^{b} \\
4^{b} \\
8\end{array}$ & $\begin{array}{l}0.5 \\
0.4 \\
1.5 \\
4.0 \\
0.2 \\
0.7\end{array}$ & $\begin{array}{r}4.8 \\
1.9 \\
12.0 \\
4.0 \\
0.5 \\
3.2\end{array}$ & $\begin{array}{l}2.1 \\
1.1 \\
4.1 \\
4.0 \\
0.3 \\
1.8\end{array}$ & $\begin{array}{l}2.0 \\
1.0 \\
3.0 \\
2.5 \\
0.1 \\
0.0\end{array}$ & $\begin{array}{l}0.3 \\
0.0 \\
0.2 \\
1.1 \\
0.0 \\
0.0\end{array}$ & $\begin{array}{l}2.0 \\
1.0 \\
3.0 \\
2.6 \\
0.1 \\
0.0\end{array}$ \\
\hline 9.0 & $\begin{array}{l}\text { Blue Catfish } \\
\text { Channel Catfish } \\
\text { Flathead Catfish } \\
\text { Small Mouth Buffalo } \\
\text { Bluegill } \\
\text { Largemouth Bass } \\
\end{array}$ & $\begin{array}{l}17 \\
15 \\
27 \\
1^{b} \\
5^{b} \\
6 \\
\end{array}$ & $\begin{array}{l}0.3 \\
0.4 \\
1.8 \\
5.1 \\
0.1 \\
0.1 \\
\end{array}$ & $\begin{array}{r}10.8 \\
2.1 \\
16.4 \\
5.1 \\
0.2 \\
4.6 \\
\end{array}$ & $\begin{array}{l}2.8 \\
1.0 \\
5.6 \\
5.1 \\
0.2 \\
1.9 \\
\end{array}$ & $\begin{array}{l}1.8 \\
0.8 \\
1.6 \\
3.0 \\
0.1 \\
0.2\end{array}$ & $\begin{array}{l}0.3 \\
0.1 \\
0.1 \\
2.1 \\
0.0 \\
0.0\end{array}$ & $\begin{array}{l}1.8 \\
0.8 \\
1.7 \\
3.2 \\
0.1 \\
0.2\end{array}$ \\
\hline \multicolumn{3}{|c|}{$\begin{array}{l}\text { a } \quad .5 \text { - Leaf River just below Hattiesburg wastewater } \\
\text { treatment plant outfall } \\
\text { 1.0 - Leaf River at National Guard Landing } \\
\text { 2.0 - Leaf River } 2 \text { miles downstream of Highway } 29 \\
\text { 4.0 - Leaf River at Beaumont }\end{array}$} & & \multicolumn{5}{|c|}{$\begin{array}{l}\text { 5.0 - Leaf River at McLain } \\
\text { 6.0 - Leaf River at Merrill } \\
\text { 7.0 - Pascagoula River at Big Creek } \\
\text { 9.0 - Pascagoula River at Black Creek }\end{array}$} \\
\hline
\end{tabular}


Table 12. Weighted mean concentrations of 2,3,7,8 tetracloro-dibenzo-p-dioxin (TCDD) and 2,3,7,8 tetraclorodibenzofuran (TCDF) in fish tissue samples from the Leaf and Pascagoula Rivers, Mississippi,1993

[no., number; pg/g, picograms per gram (parts per trillion); Min, minimum; Max, maximum; TEC, toxicity equivalence]

\begin{tabular}{|c|c|c|c|c|c|c|c|c|}
\hline \multirow[t]{2}{*}{ Site number and name } & \multirow[t]{2}{*}{ Common name } & \multirow{2}{*}{$\begin{array}{l}\text { No. } \\
\text { fish }\end{array}$} & \multicolumn{3}{|c|}{$\begin{array}{c}\text { Weight } \\
\text { (pounds) }\end{array}$} & \multicolumn{3}{|c|}{$\begin{array}{l}\text { Dioxin } \\
\text { (pg/g) }\end{array}$} \\
\hline & & & Min & Max & Mean & TCDD & TCDF & TEC \\
\hline $\begin{array}{l}0.5 \text { - Leaf River just below } \\
\text { Hattiesburg wastewater } \\
\text { treatment plant outfall }\end{array}$ & $\begin{array}{l}\text { Bigmouth Buffalo } \\
\text { Channel Catfish } \\
\text { Flathead Catfish } \\
\text { Smallmouth } \\
\text { Buffalo }\end{array}$ & $\begin{array}{l}2^{\mathrm{a}} \\
22 \\
15 \\
2^{\mathrm{a}}\end{array}$ & $\begin{array}{r}14.8 \\
0.6 \\
2.7 \\
7.1\end{array}$ & $\begin{array}{r}19.2 \\
2.2 \\
20.9 \\
9.6\end{array}$ & $\begin{array}{r}17.0 \\
1.2 \\
8.6 \\
8.3\end{array}$ & $\begin{array}{l}1.4 \\
0.5 \\
1.8 \\
0.6\end{array}$ & $\begin{array}{l}3.6 \\
0.0 \\
0.4 \\
0.8\end{array}$ & $\begin{array}{l}1.8 \\
0.5 \\
1.8 \\
0.7\end{array}$ \\
\hline $\begin{array}{l}1.0 \text { - Leaf River at National } \\
\text { Guard Landing }\end{array}$ & $\begin{array}{l}\text { Channel Catfish } \\
\text { Flathead Catfish } \\
\text { Smallmouth } \\
\text { Buffalo }\end{array}$ & $\begin{array}{r}16 \\
24 \\
9\end{array}$ & $\begin{array}{l}0.6 \\
2.2 \\
4.5\end{array}$ & $\begin{array}{r}2.1 \\
22.1 \\
13.1\end{array}$ & $\begin{array}{l}1.2 \\
8.6 \\
6.9\end{array}$ & $\begin{array}{l}0.4 \\
3.3 \\
2.0\end{array}$ & $\begin{array}{l}0.0 \\
0.2 \\
1.1\end{array}$ & $\begin{array}{l}0.4 \\
3.3 \\
2.1\end{array}$ \\
\hline $\begin{array}{l}2.0 \text { - Leaf River } 2 \text { miles } \\
\text { downstream of Highway } 29\end{array}$ & $\begin{array}{l}\text { Channel Catfish } \\
\text { Flathead Catfish } \\
\text { Smallmouth } \\
\text { Buffalo }\end{array}$ & $\begin{array}{r}20 \\
21 \\
6\end{array}$ & $\begin{array}{l}0.5 \\
2.4 \\
6.5\end{array}$ & $\begin{array}{r}2.4 \\
22.1 \\
13.1\end{array}$ & $\begin{array}{r}1.2 \\
10.0 \\
9.3\end{array}$ & $\begin{array}{l}0.6 \\
8.7 \\
1.3\end{array}$ & $\begin{array}{l}0.0 \\
0.2 \\
3.9\end{array}$ & $\begin{array}{l}0.6 \\
8.7 \\
1.7\end{array}$ \\
\hline 4.0 - Leaf River at Beaumont & $\begin{array}{l}\text { Channel Catfish } \\
\text { Flathead Catfish } \\
\text { Smallmouth } \\
\text { Buffalo }\end{array}$ & $\begin{array}{r}19 \\
25 \\
8\end{array}$ & $\begin{array}{l}0.4 \\
2.1 \\
2.9\end{array}$ & $\begin{array}{r}13.2 \\
25.8 \\
8.0\end{array}$ & $\begin{array}{l}1.8 \\
6.9 \\
4.6\end{array}$ & $\begin{array}{l}3.7 \\
2.2 \\
2.1\end{array}$ & $\begin{array}{l}0.2 \\
0.1 \\
1.9\end{array}$ & $\begin{array}{l}3.7 \\
2.2 \\
2.3\end{array}$ \\
\hline 5.0 - Leaf River at McLain & $\begin{array}{l}\text { Channel Catfish } \\
\text { Flathead Catfish } \\
\text { Smallmouth } \\
\text { Buffalo }\end{array}$ & $\begin{array}{l}17 \\
20 \\
11\end{array}$ & $\begin{array}{l}0.6 \\
1.6 \\
2.4\end{array}$ & $\begin{array}{r}2.5 \\
25.0 \\
12.0\end{array}$ & $\begin{array}{l}1.3 \\
6.1 \\
4.8\end{array}$ & $\begin{array}{l}0.2 \\
2.2 \\
1.2\end{array}$ & $\begin{array}{l}0.1 \\
0.0 \\
1.4\end{array}$ & $\begin{array}{l}0.2 \\
2.2 \\
1.3\end{array}$ \\
\hline 6.0 - Leaf River at Merrill & $\begin{array}{l}\text { Channel Catfish } \\
\text { Flathead Catfish } \\
\text { Smallmouth } \\
\text { Buffalo }\end{array}$ & $\begin{array}{l}13 \\
22 \\
13\end{array}$ & $\begin{array}{l}0.4 \\
2.6 \\
3.4\end{array}$ & $\begin{array}{r}1.9 \\
17.5 \\
10.6\end{array}$ & $\begin{array}{l}0.8 \\
6.7 \\
6.4\end{array}$ & $\begin{array}{l}0.5 \\
2.5 \\
3.2\end{array}$ & $\begin{array}{l}0.0 \\
0.2 \\
3.5\end{array}$ & $\begin{array}{l}0.5 \\
2.5 \\
3.6\end{array}$ \\
\hline $\begin{array}{l}7.0 \text { - Pascagoula River at Big } \\
\text { Creek }\end{array}$ & $\begin{array}{l}\text { Blue Catfish } \\
\text { Channel Catfish } \\
\text { Flathead Catfish } \\
\text { Smallmouth } \\
\text { Buffalo }\end{array}$ & $\begin{array}{r}7 \\
13 \\
20 \\
8\end{array}$ & $\begin{array}{l}0.9 \\
0.5 \\
2.2 \\
2.6\end{array}$ & $\begin{array}{r}3.9 \\
1.3 \\
14.5 \\
6.8\end{array}$ & $\begin{array}{l}1.9 \\
0.9 \\
7.2 \\
4.7\end{array}$ & $\begin{array}{l}1.1 \\
0.8 \\
2.1 \\
1.2\end{array}$ & $\begin{array}{l}0.0 \\
0.0 \\
0.1 \\
0.7\end{array}$ & $\begin{array}{l}1.1 \\
0.8 \\
2.1 \\
1.3\end{array}$ \\
\hline
\end{tabular}

a Actual (rather than weighted mean) dioxin concentrations are shown for species having 5 or fewer fish sampled. 
Table 13. Weighted mean concentrations of 2,3,7,8 tetracloro-dibenzo-p-dioxin (TCDD) and 2,3,7,8 tetraclorodibenzofuran (TCDF) in fish tissue samples from the Leaf and Pascagoula Rivers, Mississippi, 1994

[no., number; pg/g, picograms per gram, (parts per trillion); Min, Minimum; Max, Maximum; TEC, toxicity equivalence]

\begin{tabular}{|c|c|c|c|c|c|c|c|c|}
\hline \multirow[t]{2}{*}{ Site number and name } & \multirow[t]{2}{*}{ Common name } & \multirow{2}{*}{$\begin{array}{l}\text { No. } \\
\text { fish }\end{array}$} & \multicolumn{3}{|c|}{$\begin{array}{c}\text { Weight } \\
\text { (pounds) }\end{array}$} & \multicolumn{3}{|c|}{$\begin{array}{l}\text { Dioxin } \\
(\mathrm{pg} / \mathrm{g})\end{array}$} \\
\hline & & & Min & Max & Mean & TCDD & TCDF & TEC \\
\hline $\begin{array}{l}0.5 \text { - Leaf River just below } \\
\text { Hattiesburg waste water } \\
\text { treatment plant outfall }\end{array}$ & Flathead Catfish & 15 & 5.3 & 24.8 & 10.1 & 2.4 & 0.3 & 2.4 \\
\hline $\begin{array}{l}1.5 \text { - Leaf River just above } \\
\text { Tallahala Creek }\end{array}$ & Flathead Catfish & 18 & 5.4 & 22.9 & 9.4 & 2.8 & 0.1 & 2.8 \\
\hline $\begin{array}{l}2.0 \text { - Leaf River } 2 \text { miles } \\
\text { downstream of Highway } 29\end{array}$ & $\begin{array}{l}\text { Channel Catfish } \\
\text { Flathead Catfish }\end{array}$ & $\begin{array}{c}5^{\mathrm{a}} \\
15\end{array}$ & $\begin{array}{l}1.3 \\
4.6\end{array}$ & $\begin{array}{r}2.9 \\
14.0\end{array}$ & $\begin{array}{l}2.0 \\
7.7\end{array}$ & $\begin{array}{l}0.8 \\
1.3\end{array}$ & $\begin{array}{l}0.1 \\
0.0\end{array}$ & $\begin{array}{l}0.8 \\
1.3\end{array}$ \\
\hline 4.0 - Leaf River at Beaumont & $\begin{array}{l}\text { Channel Cattish } \\
\text { Flathead Catfish }\end{array}$ & $\begin{array}{l}2^{\mathrm{a}} \\
16\end{array}$ & $\begin{array}{l}3.6 \\
4.9\end{array}$ & $\begin{array}{r}4.3 \\
22.9\end{array}$ & $\begin{array}{l}4.0 \\
8.1\end{array}$ & $\begin{array}{l}0.8 \\
2.1\end{array}$ & $\begin{array}{l}0.1 \\
0.1\end{array}$ & $\begin{array}{l}0.8 \\
2.1\end{array}$ \\
\hline 5.0 - Leaf River at McLain & Flathead Catfish & 20 & 5.8 & 25.1 & 10.6 & 4.8 & 0.1 & 4.8 \\
\hline 6.0 - Leaf River at Merrill & Flathead Catfish & 18 & 5.2 & 26.4 & 9.8 & 1.8 & 0.3 & 1.8 \\
\hline
\end{tabular}

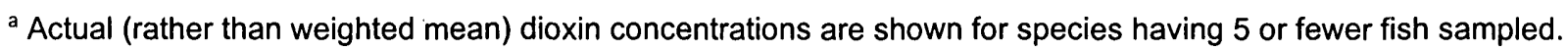

Table 14. Weighted mean concentrations of 2,3,7,8 tetracloro-dibenzo-p-dioxin (TCDD) and 2,3,7,8 tetraclorodibenzofuran (TCDF) in fish tissue samples from the Leaf and Pascagoula Rivers, Mississippi, 1995

[no., number; pg/g, picograms per gram (parts per trillion); Min, Minimum weight; Max, Maximum weight; TEC, toxicity equivalence; $<$, nondetection, reported as less than value]

\begin{tabular}{|c|c|c|c|c|c|c|c|c|}
\hline \multirow[t]{2}{*}{ Site number and name } & \multirow[t]{2}{*}{ Common name } & \multirow{2}{*}{$\begin{array}{l}\text { No. } \\
\text { fish }\end{array}$} & \multicolumn{3}{|c|}{$\begin{array}{l}\text { Weight } \\
\text { (pounds) }\end{array}$} & \multicolumn{3}{|c|}{$\begin{array}{l}\text { Dioxin } \\
(\mathrm{pg} / \mathrm{g})\end{array}$} \\
\hline & & & Min & Max & Mean & TCDD & TCDF & TEC \\
\hline $\begin{array}{l}0.5 \text { - Leaf River just below } \\
\text { Hattiesburg wastewater } \\
\text { treatment plant outfall }\end{array}$ & Flathead Catfish & 11 & 6.5 & 15.7 & 11.4 & 0.9 & 0.5 & 1.0 \\
\hline $\begin{array}{l}1.5 \text { - Leaf River just above } \\
\text { Tallahala Creek }\end{array}$ & Flathead Catfish & 16 & 5.2 & 25.6 & 12.5 & 3.5 & 0.1 & 3.5 \\
\hline $\begin{array}{l}2.0 \text { - Leaf River } 2 \text { miles } \\
\text { downstream of Highway } 29\end{array}$ & $\begin{array}{l}\text { Flathead Catfish } \\
\text { Channel Catfish }\end{array}$ & $\begin{array}{c}11 \\
4^{\mathrm{a}}\end{array}$ & $\begin{array}{l}6.0 \\
1.6\end{array}$ & $\begin{array}{r}26.8 \\
2.1\end{array}$ & $\begin{array}{r}13.7 \\
1.8\end{array}$ & $\begin{array}{l}1.8 \\
0.4\end{array}$ & $\begin{array}{r}0.1 \\
<0.1\end{array}$ & $\begin{array}{l}1.8 \\
0.4\end{array}$ \\
\hline 4.0 - Leaf River at Beaumont & $\begin{array}{l}\text { Flathead Catfish } \\
\text { Channel Catfish }\end{array}$ & $\begin{array}{c}10 \\
5^{a}\end{array}$ & $\begin{array}{l}5.0 \\
2.5\end{array}$ & $\begin{array}{r}23.9 \\
3.6\end{array}$ & $\begin{array}{r}12.2 \\
3.0\end{array}$ & $\begin{array}{l}0.8 \\
0.6\end{array}$ & $\begin{array}{l}0.5 \\
0.1\end{array}$ & $\begin{array}{l}0.9 \\
0.7\end{array}$ \\
\hline 5.0 - Leaf River at McLain & Flathead Catfish & 12 & 5.4 & 16.8 & 10.9 & 1.9 & 0.0 & 1.9 \\
\hline 6.0 - Leaf River at Merrill & Flathead Catfish & 8 & 5.4 & 13.6 & 9.1 & 2.4 & 0.2 & 2.4 \\
\hline
\end{tabular}

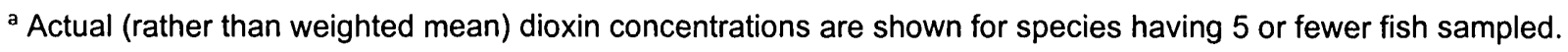


Table 15. Weighted mean concentrations of 2,3,7,8 tetracloro-dibenzo-p-dioxin (TCDD) and 2,3,7,8 tetraclorodibenzofuran (TCDF) in fish tissue samples from the Leaf and Pascagoula Rivers, Mississippi, 1996

[no., number; pg/g, parts per gram (parts per trillion); Min, Minimum; Max, Maximum; TEC, toxicity equivalence; $<$, nondetection, reported as less than value]

\begin{tabular}{|c|c|c|c|c|c|c|c|c|}
\hline \multirow[t]{2}{*}{ Site number and name } & \multirow[t]{2}{*}{ Common name } & \multirow{2}{*}{$\begin{array}{l}\text { No. } \\
\text { fish }\end{array}$} & \multicolumn{3}{|c|}{$\begin{array}{l}\text { Weight } \\
\text { (pounds) }\end{array}$} & \multicolumn{3}{|c|}{$\begin{array}{l}\text { Dioxin } \\
\text { (pg/g) }\end{array}$} \\
\hline & & & Min & $\operatorname{Max}$ & Mean & TCDD & TCDF & TEC \\
\hline $\begin{array}{l}0.5 \text { - Leaf River just below } \\
\text { Hattiesburg wastwater } \\
\text { treatment plant outfall }\end{array}$ & Flathead Catfish & 8 & 5.5 & 12.2 & 8.4 & 0.3 & 0.4 & 0.3 \\
\hline $\begin{array}{l}1.5 \text { - Leaf River just above } \\
\text { Tallahala Creek }\end{array}$ & Flathead Catfish & 11 & 6.3 & 22.9 & 12.8 & 0.4 & 0.2 & 0.4 \\
\hline $\begin{array}{l}2.0 \text { - Leaf River } 2 \text { miles } \\
\text { downstream of Highway } 29\end{array}$ & $\begin{array}{l}\text { Flathead Catfish } \\
\text { Channel Catfish }\end{array}$ & $\begin{array}{l}5^{\mathrm{a}} \\
5^{\mathrm{a}}\end{array}$ & $\begin{array}{l}5.5 \\
1.0\end{array}$ & $\begin{array}{l}7.5 \\
1.5\end{array}$ & $\begin{array}{l}6.6 \\
1.2\end{array}$ & $\begin{array}{l}0.5 \\
0.3\end{array}$ & $\begin{array}{l}0.1 \\
<0.0036\end{array}$ & $\begin{array}{l}0.5 \\
0.3\end{array}$ \\
\hline 4.0 - Leaf River at Beaumont & $\begin{array}{l}\text { Flathead Catfish } \\
\text { Channel Catfish }\end{array}$ & $\begin{array}{l}6 \\
5^{\mathrm{a}}\end{array}$ & $\begin{array}{l}5.3 \\
1.3\end{array}$ & $\begin{array}{r}22.0 \\
1.8\end{array}$ & $\begin{array}{r}12.5 \\
1.6\end{array}$ & $\begin{array}{c}0.5 \\
<0.35\end{array}$ & $\begin{array}{l}0.1 \\
<0.055\end{array}$ & $\begin{array}{l}0.5 \\
0.0\end{array}$ \\
\hline 5.0 - Leaf River at McLain & Flathead Catfish & 9 & 6.1 & 22.5 & 13.1 & 1.2 & 0.1 & 1.2 \\
\hline
\end{tabular}

actual (rather than weighted mean) dioxin concentrations are shown for species having 5 or fewer fish sampled.

Table 16. Concentrations of 2,3,7,8 tetracloro-dibenzo-p-dioxin (TCDD) and 2,3,7,8 tetraclorodibenzofuran (TCDF) in fish tissue samples from the Leaf and Pascagoula Rivers, Mississippi, 1997

[no., number; pg/g, picograms per gram (parts per trillion); Min, Minimum; Max, Maximum; TEC, toxicity equivalence; $<$, nondetection, reported as less than value]

\begin{tabular}{|c|c|c|c|c|c|c|c|c|}
\hline \multirow{2}{*}{ Site number and name } & \multirow{2}{*}{ Common name } & \multirow{2}{*}{$\begin{array}{l}\text { No. } \\
\text { fish }\end{array}$} & \multicolumn{3}{|c|}{$\begin{array}{l}\text { Weight } \\
\text { (pounds) }\end{array}$} & \multicolumn{3}{|c|}{$\begin{array}{l}\text { Dioxin } \\
\text { (pg/g) }\end{array}$} \\
\hline & & & Min & Max & Mean & TCDD & TCDF & TEC \\
\hline $\begin{array}{l}1.5 \text { - Leaf River just above } \\
\text { Tallahala Creek }\end{array}$ & Channel Catfish & $5^{a}$ & 1.0 & 1.5 & 1.3 & 1 & $<1.00$ & 0 \\
\hline $\begin{array}{l}2.0 \text { - Leaf River } 2 \text { miles } \\
\text { downstream of Highway } 29\end{array}$ & Channel Catfish & $5^{a}$ & 1.0 & 1.6 & 1.4 & $<1.00$ & $<1.00$ & 0 \\
\hline \multirow[t]{2}{*}{ 4.0 - Leaf River at Beaumont } & Channel Catfish & $5^{a}$ & 1.4 & 2.3 & 2.1 & $<1.00$ & $<1.00$ & 0 \\
\hline & Flathead Catfish & $3^{a}$ & 4.9 & 6.3 & 5.2 & $<1.00$ & $<1.00$ & 0 \\
\hline
\end{tabular}

actual (rather than weighted mean) dioxin concentrations are shown for species having 5 or fewer fish sampled. 


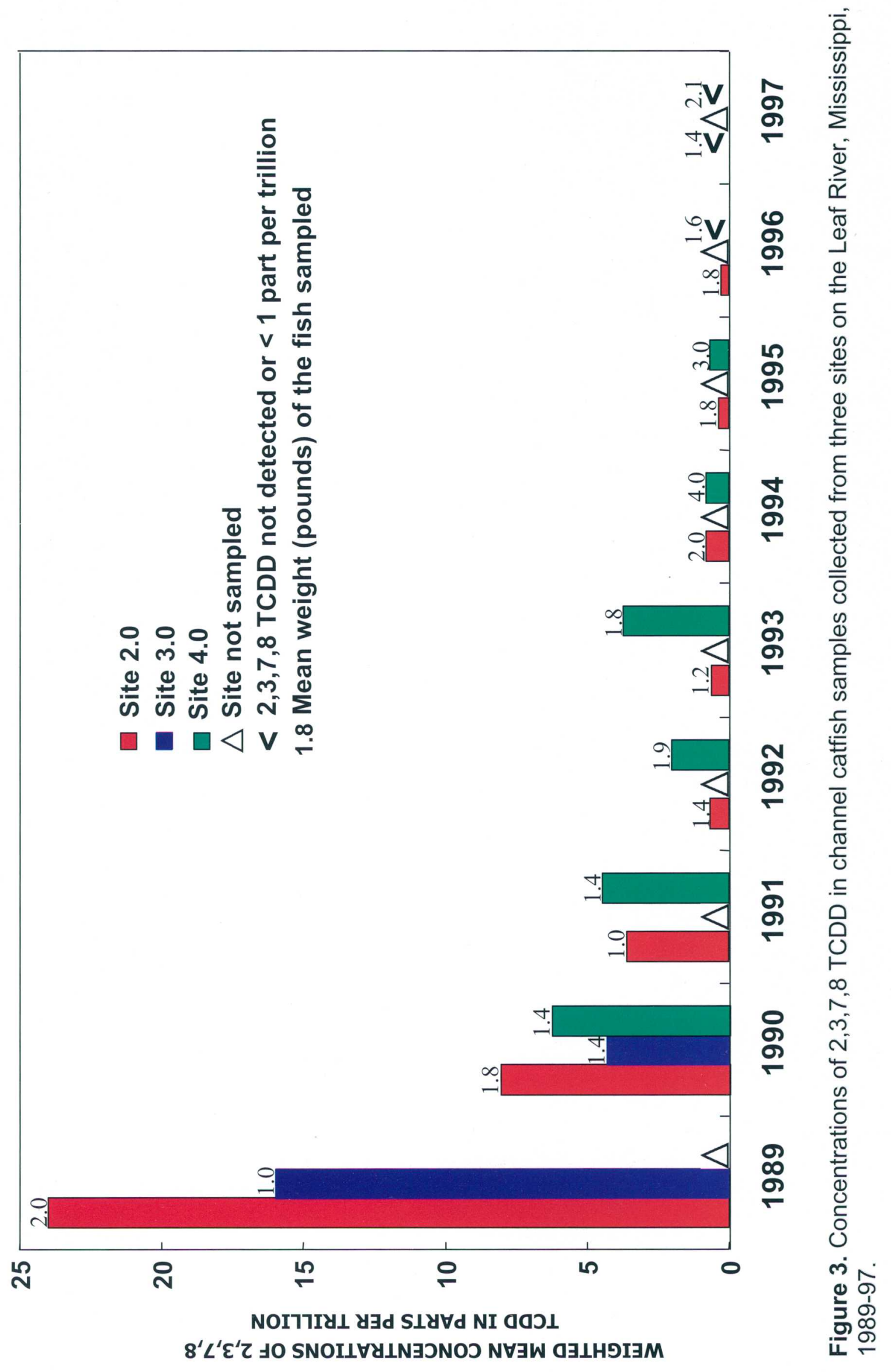




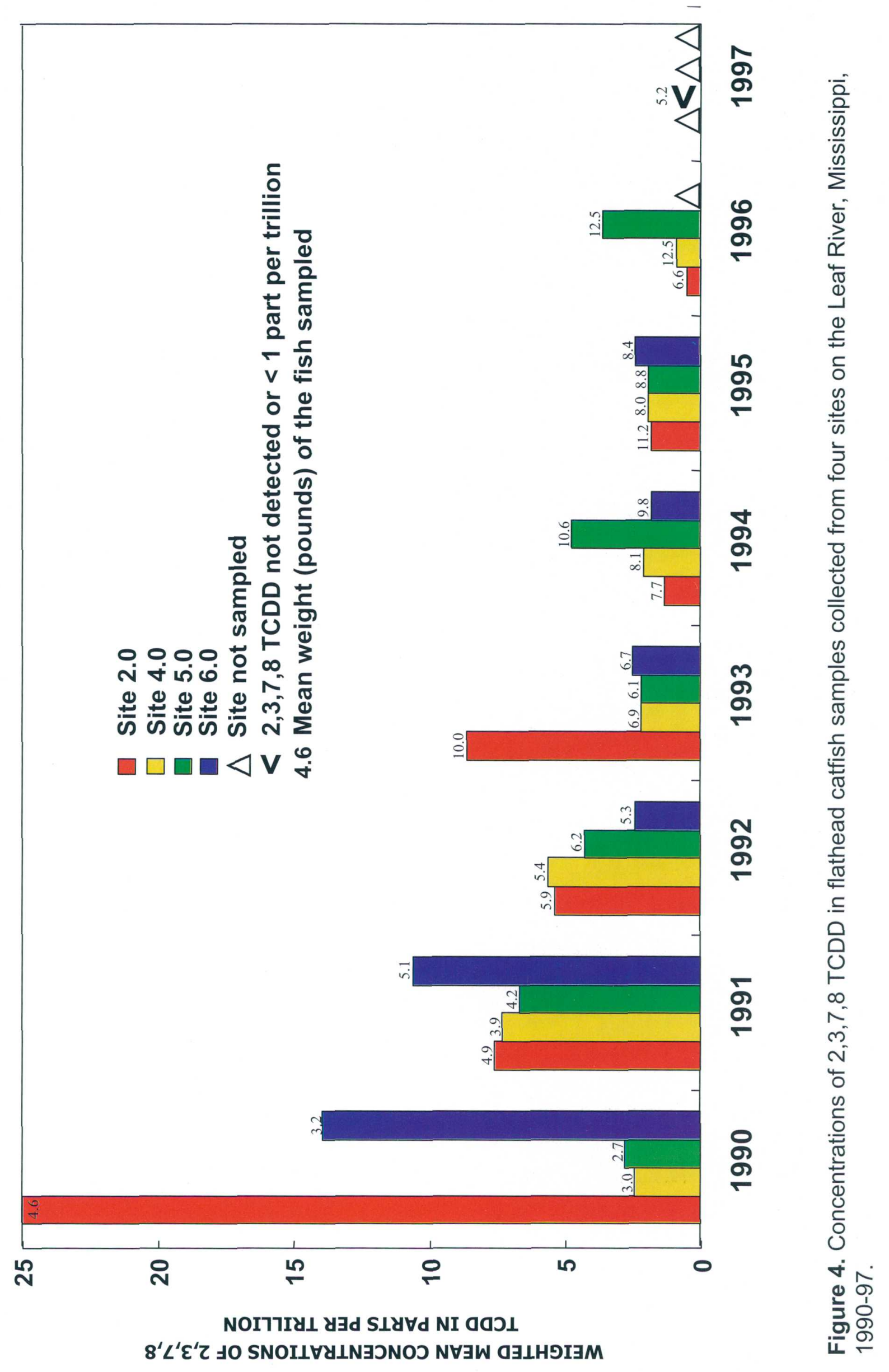




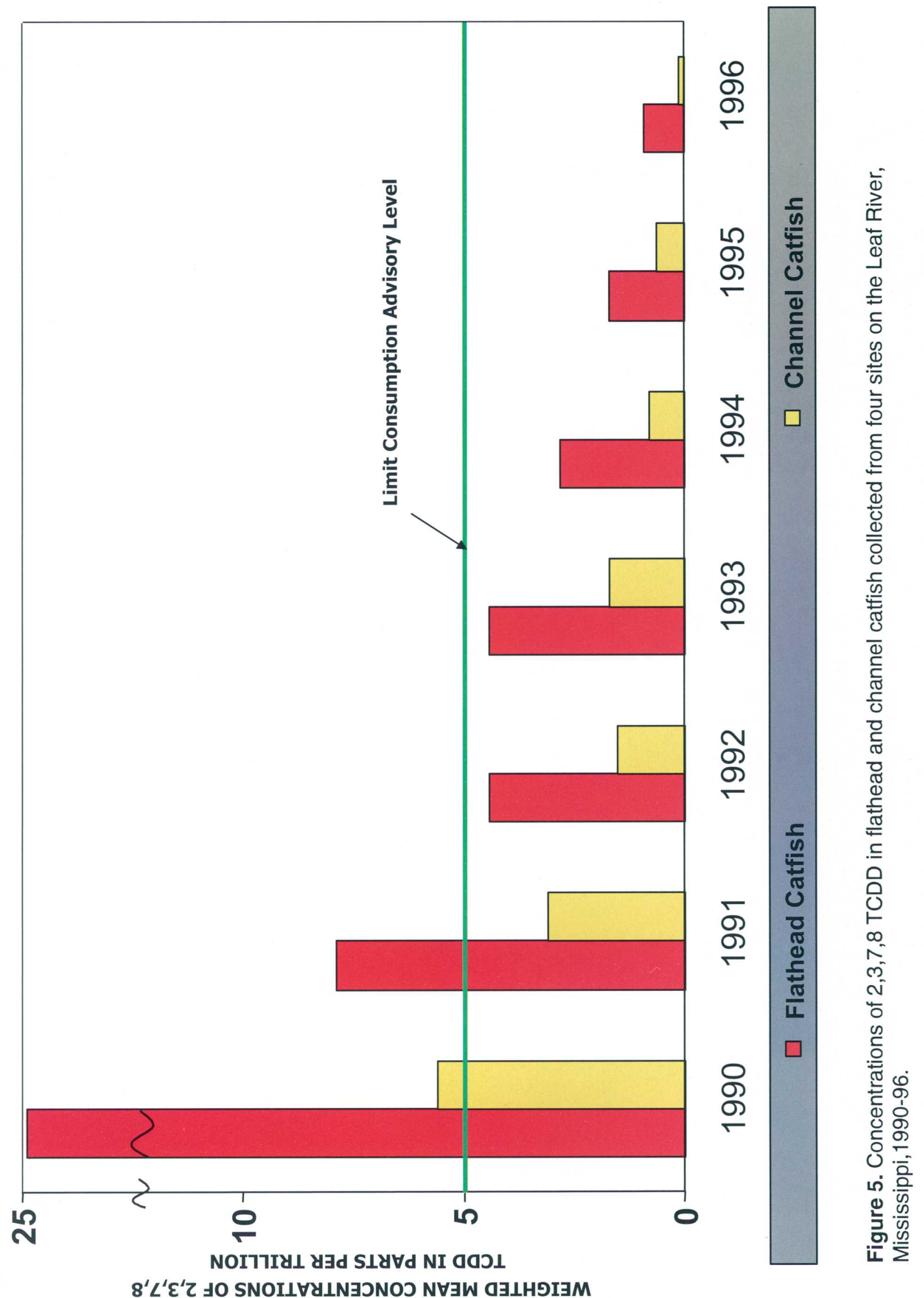




\section{Effluent Data}

Effluent analyses conducted by the mill in the mid to late 1980's detected 2378 TCDD at more than $100 \mathrm{pg} / \mathrm{l}$ (Acker Smith, Leaf River Forest Products, written commun., 1998). However, 2378 TCDD was not detected in 15 effluent samples collected by the MDEQ in 1992, and 2378 TCDF was detected in only two of the 15 samples at low concentrations (table 17). This reduction was probably due to the modifications made by the mill to the bleaching process, which eliminated a major source of dioxins.

Table 17. Concentrations of $2,3,7,8$ tetracloro-dibenzo-p-dioxin (TCDD) and 2,3,7,8 tetraclorodibenzofuran (TCDF) in water samples collected from a paper mill effluent discharging into the Leaf River, January 1993 - October 1994

[pg/l, picograms per liter (parts per quadrillion); ND, nondetect results were lost; RL, results were lost; <, nondetection, reported as less than value]

\begin{tabular}{|lcc|}
\hline \multicolumn{1}{|c}{ Date } & $\begin{array}{c}\text { TCDD } \\
(\mathrm{pg} / \mathrm{l})\end{array}$ & $\begin{array}{c}\text { TCDF } \\
(\mathrm{pg} / \mathrm{l})\end{array}$ \\
\hline January 1993 & $<9.65$ & $<10.5$ \\
\hline February 1993 & $<8.5$ & $<5.5$ \\
\hline March 1993 & $<8.6$ & $<5.9$ \\
\hline April 1993 & $<4.5$ & $<3.7$ \\
\hline May 1993 & $<5.9$ & $<3.9$ \\
\hline June 1993 & $<1.3$ & 1.9 \\
\hline July 1993 & $<6.6$ & $<4.8$ \\
\hline August 1993 & $<2.2$ & 7.6 \\
\hline September 1993 & $<4.8$ & $<2.8$ \\
\hline October 1993 & $<1.7$ & $(4.8)$ \\
\hline November 1993 & $<8.8$ & $<7.5$ \\
\hline December 1993 & ND & ND \\
\hline January 1994 & $<2.0$ & $<1.6$ \\
\hline April 1994 & ND & ND \\
\hline July 1994 & ND 31 & ND \\
\hline October 1994 & RL & RL \\
\hline
\end{tabular}

\section{Caddisfly Data}

Caddisfly tissue was analyzed to determine 2378 TCDD and 2378 TCDF concentrations in secondary food chain organisms. Concentrations of 2378 TCDD and TCDF in caddisfly tissue were highest in 1989 samples, and the less toxic $2378 \mathrm{TCDF}$ congener was detected more frequently than 2378 TCDD (table 18). By 1990, concentrations of both congeners had decreased to near the detection limit (1 pg/g), and in October 1990 there was only one detection of 2378 TCDD for the six sites sampled. In 1991, there were no detections of $2378 \mathrm{TCDD}$, and the number of detections for 2378 TCDF decreased from five in July to one in September; concentrations were substantially lower than 1989 levels. In contrast, 2378 TCDD and 2378 TCDF concentrations increased from 1991 to 1992 following the June 1992 sludge spill, and concentrations of both congeners in samples collected in October 1992 were the highest since 1989. This detection of the two dioxin congeners at these concentrations is an indication that dioxins were introduced to the lower food chain by the 1992 sludge spill, but it is not evident if dioxins were biomagnified through the food chain.

\section{Streambed-Sediment Data}

Thirty-seven percent of sediment samples collected in 1989 had concentrations above detection limits for 2378 TCDD or 2378 TCDF. Five of the six detections were at sites downstream of the mill discharge (table 19), suggesting that the mill may have been the source of these congeners. Of the three samples that had detectable concentrations of 2378 TCDD, all had concentrations lower than $1 \mathrm{pg} / \mathrm{g}$. Because the EPA suggests that $2.5 \mathrm{pg} / \mathrm{g} 2378$ TCDD in sediment can be used as a level of "low risk to sensitive mammalian wildlife" (U.S. Environmental Protection Agency, 1993), these concentrations were not considered to be threatening. 


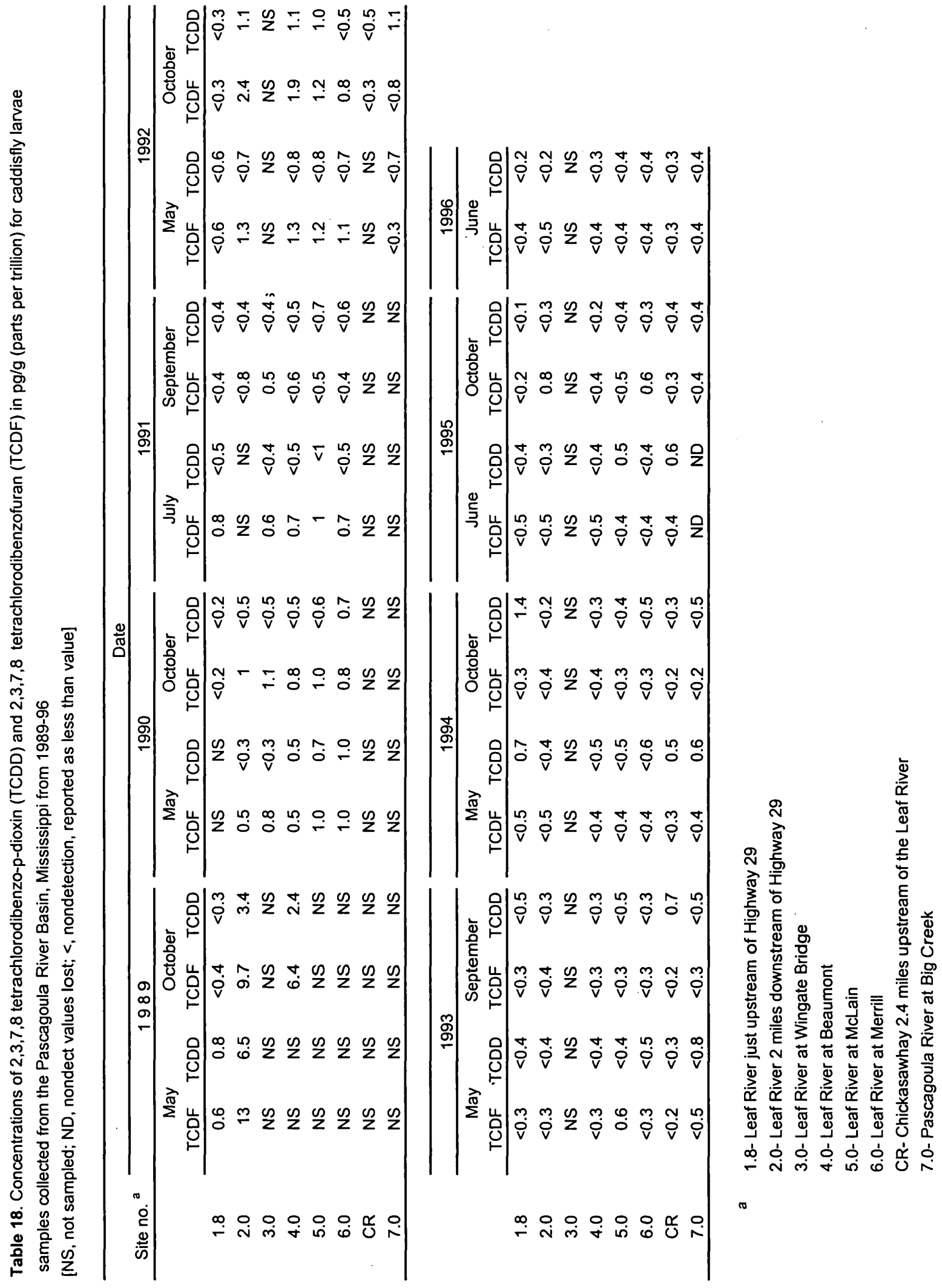


Table 19. Concentrations of $2,3,7,8$

tetrachlorodibenzo-p-dioxin (TCDD), 2,3,7,8, tetrachlorodibenzofuran (TCDF), and total organic carbon (TOC) in sediment samples collected from the Leaf River Basin, Mississippi, 1989

[pg/g, picograms per gram (parts per trillion); $\mathrm{mg} / \mathrm{kg}$, milligrams per kilogram (parts per million); <, nondetection, reported as less than value]

\begin{tabular}{lccc}
\hline Site number and name & $\begin{array}{c}\text { TCDD } \\
(\mathrm{pg} / \mathrm{g})\end{array}$ & $\begin{array}{c}\text { TCDF } \\
(\mathrm{pg} / \mathrm{g})\end{array}$ & $\begin{array}{c}\mathrm{TOC} \\
(\mathrm{mg} / \mathrm{kg})\end{array}$ \\
\hline $\begin{array}{l}\text { 0.5 - Leaf River just } \\
\text { below the Hattiesburg } \\
\text { wastewater treatment } \\
\text { plant outfall }\end{array}$ & 0.6 & $<0.2$ & 4500 \\
$\begin{array}{l}1.3 \text { - Leaf River 10 } \\
\text { miles above mill } \\
\text { discharge }\end{array}$ & $<0.3$ & $<0.9$ & 1200 \\
$\begin{array}{l}2.0 \text { - Leaf River 2 } \\
\text { miles downstream of } \\
\text { Highway 29 }\end{array}$ & $<0.4$ & $<0.2$ & 800 \\
$\begin{array}{l}3.0 \text { - Leaf River at } \\
\text { Wingate Bridge }\end{array}$ & 0.5 & 0.3 & 4700 \\
$\begin{array}{l}5.0 \text { - Leaf River at } \\
\text { McLain }\end{array}$ & 0.9 & 1.2 & 4900 \\
$\begin{array}{l}\text { TA - Tallahala Creek } \\
10 \text { miles upstream } \\
\text { from Leaf River }\end{array}$ & $<0.5$ & 0.2 & 3100 \\
$\begin{array}{l}\text { BH - Bogue Homa } \\
\text { Creek 10 miles } \\
\text { upstream from Leaf }\end{array}$ & $<0.4$ & $<0.1$ & 13000 \\
River & & & \\
$\begin{array}{l}\text { TH - Thompsons } \\
\text { Creek 10 miles } \\
\text { upstream from Leaf } \\
\text { River }\end{array}$ & $<0.3$ & $<0.1$ & 13000 \\
\hline & & & \\
\hline
\end{tabular}

Results for 1992 streambed-sediment data were comparable to those for 1989 for concentrations of 2378 TCDD and 2378 TCDF (table 20). For the other PCDD/Fs measured in 1992 samples, concentrations in sediments were highest for HXCDD, HPCDD, and OCDD, which are more common and widespread than the TCDD and PCCDD dioxins. When total concentrations of PCDD/Fs in replicate samples were compared, there was more than 50 percent variability at 5 of the 11 sites sampled. Most of this variability was associated with TOC and 12346789 OCDD concentrations, and this was also noted in other studies of dioxins in sediments from the Leaf and Pascagoula River (Fiedler, 1996; Rappe, 1997). However, it should be noted that the 12346789 OCDD and 12346789 OCDF congeners are the least toxic and water soluble of the PCDD/Fs measured. The 12346789 OCDD congener accounted for a higher percentage of total concentrations of all PCDD/Fs compared to other basins (Fiedler, 1996; Bonn, 1998). Concentrations of 12346789 OCDD for all samples were highly correlated $\left(r^{2}>0.90\right)$ with TEC and total concentrations of all PCDD/Fs. About 91 percent (20 of 22) of the samples exceeded a range of concentrations considered by EPA to be background for PCDD/Fs in sediments for the United States (400-900 parts per trillion, U.S. Environmental Protection Agency, 1993), and the remaining two samples fell within the range. However, because OCDDs may be higher in the Pascagoula River Basin than in other basins from which the criteria were developed, and because most of the toxicity of the TEC calculation is contributed by OCDDs, it is not known if these criteria are applicable to the Pascagoula River Basin.

The highest PCDD/F concentrations and the most detections were measured at site 4.0 on the Leaf River and at site 9.0 on the Pascagoula River. The source of dioxins at these sites (or other sites) for the 1992 data is not certain. With the exception of sites 4.0 and $9.0, \mathrm{PCDD} / \mathrm{F}$ concentrations at sites upstream of the mill were comparable to concentrations at sites

downstream of the mill. It is possible that wood preservatives contributed to dioxin concentrations in streambed sediments. Wood preservatives are a known source of PCCDD, HXCDD, and HPCDD dioxins (U.S.

Environmental Protection Agency, 1992a), and the wood preservative pentachlorophenol has been associated with OCDDs (Hagenmaier and Brunner, 1987). Wood-treatment facilities are known to have operated near site 4.0 , and because the forest industry is prevalent in this area, other facilities probably exist(ed) in the basin. Another potential source for pentachlorophenol is sewage treatment plant effluents. Rappe and others (1998) considered pentachlorophenol to be the primary source of high concentrations of OCDDs in sludge and effluent samples collected from sewage treatment plants in southeastern Mississippi. 


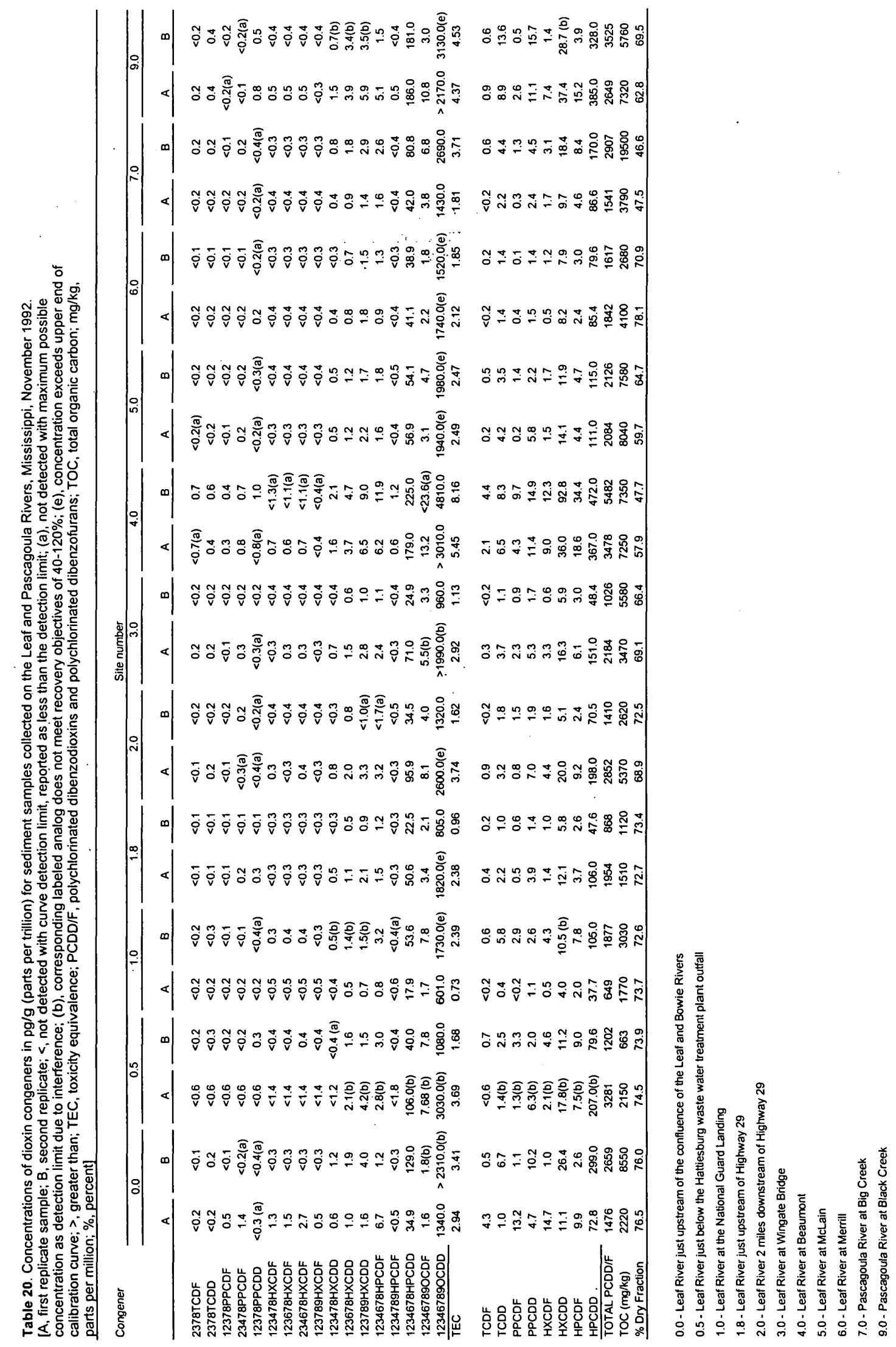




\section{Fish-Consumption Advisories}

Details of fish-tissue advisories issued for the Leaf and Pascagoula Rivers are summarized in figure 6 . The first advisory was issued late in 1989 and was based on data collected from the MCD study in May and August 1989. Dioxin (2378 TCDD) was detected at 24 and $16 \mathrm{pg} / \mathrm{g}$ in two channel catfish samples collected at sites 2.0 and 3.0 downstream of Hwy 29, and was detected at higher concentrations at sites farther downstream. A "no consumption" advisory for bottom-feeding species was issued from Hwy 29 downstream to Hwy 15 at Beaumont (a reach of river 12 miles long).

After results from the spring 1990 sampling were received, the "no consumption" advisory was extended upstream 4.5 miles to the mouth of Tallahala Creek. The advisory was extended upstream because 2378 TCDD concentrations exceeded $5 \mathrm{pg} / \mathrm{g}$ in blue and flathead catfish at site 1.0 (table 9), upstream of Hwy 29.

Data from the 1990 summer sampling effort indicated that dioxin concentrations were high in flathead catfish throughout the study area. In October 1990, the MDEQ extended the existing "no consumption" advisory approximately 30 miles downstream to Merrill, and also recommended that no flathead catfish be eaten from the Pascagoula River. At the same time the MDWFP extended the commercial fishing ban to include the new advisory area on the Leaf River and all of the Pascagoula River, a distance of approximately 122 river miles.

After the task force developed advisory criteria, the MDEQ prepared annual summaries detailing results of fish-tissue monitoring. Dioxin data in these annual reports were compared with previous data to determine trends, and with criteria established by the dioxin task force to determine if existing advisories should be modified.

In December 1990, after evaluating all the data in the 1990 annual summary, the first action of the task force was to make recommendations to change the advisory for both the Leaf and Pascagoula River reaches from a "no consumption" advisory to a "limit consumption" advisory. The MDEQ followed task force recommendations, and the MDWFP removed the commercial fishing ban at the same time. Advisory language was also changed for the Leaf River from "all bottom feeding fish" to "all catfish," and advisory language for the Pascagoula River reach was changed to pertain only to blue catfish weighing more than $5 \mathrm{lb}$.

One recommendation of the task force was that the advisory would be reviewed and, if necessary, modified annually after all samples for the year were analyzed. However, that decision was temporarily nullified on February 15, 1991, when a Mississippi chancery court judge from Hinds County ordered all of the Leaf and Pascagoula Rivers closed to "all fishing." Three weeks later, the advisory that was in place prior to the judge's ruling was reinstated after the same judge reversed her decision.

In February 1992, the task force evaluated data from 1991 and made the following change which pertained only to the Pascagoula River: advisory language was changed from "blue catfish greater than $5 \mathrm{lb}$ (or about 22 inches long)" to "all catfish greater than $5 \mathrm{lb}$." This change was made because flathead catfish samples collected from all sites downstream of Hwy 29, including samples from one site on the Pascagoula River, exceeded the "limit consumption" criteria of $5 \mathrm{pg} / \mathrm{g}$.

By 1993, it was evident that dioxin concentrations in the Leaf River were declining and that the public only need be concerned about consuming larger, older fish. It had also been determined that 2378 TCDD concentrations were higher in flathead catfish than in other species. The task force changed the advisory so that it applied only to catfish greater than $10 \mathrm{lb}$ (about 27 inches). In February 1994, based on 1993 data, the river reach covered by the advisory area was reduced from approximately 120 river miles of the Leaf and Pascagoula Rivers to 16.5 miles of the Leaf River. The 1994 advisory language remained the same; the public should refrain from eating catfish greater than $10 \mathrm{lb}$.

Weighted mean concentrations for 2378

TCDD for all channel and flathead catfish samples collected in the summer and fall sampling efforts in 1994 were less than $5 \mathrm{pg} / \mathrm{g}$ at every site. Consequently, all dioxin advisories were removed from the Pascagoula River Basin in April 1995. 


\begin{tabular}{|c|c|c|c|}
\hline \multirow[t]{3}{*}{ Date } & \multicolumn{2}{|c|}{ Advisory area (river miles) } & \multirow{3}{*}{$\begin{array}{c}\text { Size of } \\
\text { fish }\end{array}$} \\
\hline & \multirow{2}{*}{$\begin{array}{c}\text { Leaf River } \\
45\end{array}$} & \multirow[t]{2}{*}{ Pascagoula River } & \\
\hline & & & \\
\hline $11 / 20 / 89$ & 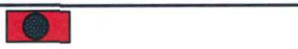 & & all \\
\hline $8 / 16 / 90$ & {$[0$} & & all \\
\hline \multirow{2}{*}{$10 / 5 / 90$} & \multirow{2}{*}{0} & & all \\
\hline & & 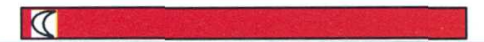 & all \\
\hline \multirow[t]{2}{*}{$12 / 21 / 90$} & \multirow[t]{2}{*}{$\sqrt{2}$} & & all \\
\hline & & & $>5 \mathrm{lb}$ \\
\hline \multirow[t]{2}{*}{$2 / 15 / 91$} & \multirow[t]{2}{*}{$\mathbf{A}$} & & all \\
\hline & & $A$ & all \\
\hline \multirow[t]{2}{*}{$3 / 5 / 91$} & \multirow[t]{2}{*}{$\sqrt{\square}$} & & $>5 \mathrm{lb}$ \\
\hline & & 1 & $>5 \mathrm{lb}$ \\
\hline \multirow[t]{2}{*}{$2 / 11 / 92$} & \multirow[t]{2}{*}{ 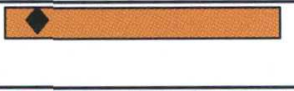 } & & $>5 \mathrm{lb}$ \\
\hline & & $\nabla$ & $>5 \mathrm{lb}$ \\
\hline \multirow[t]{2}{*}{$1 / 13 / 93$} & \multirow[t]{2}{*}{$\sqrt{5}$} & & $>10 \mathrm{lb}$ \\
\hline & & $\underline{1}$ & $>10 \mathrm{lb}$ \\
\hline $2 / 16 / 94$ & $\sqrt{\square}$ & & $>10 \mathrm{lb}$ \\
\hline $4 / 18 / 95$ & $\square$ & & \\
\hline
\end{tabular}

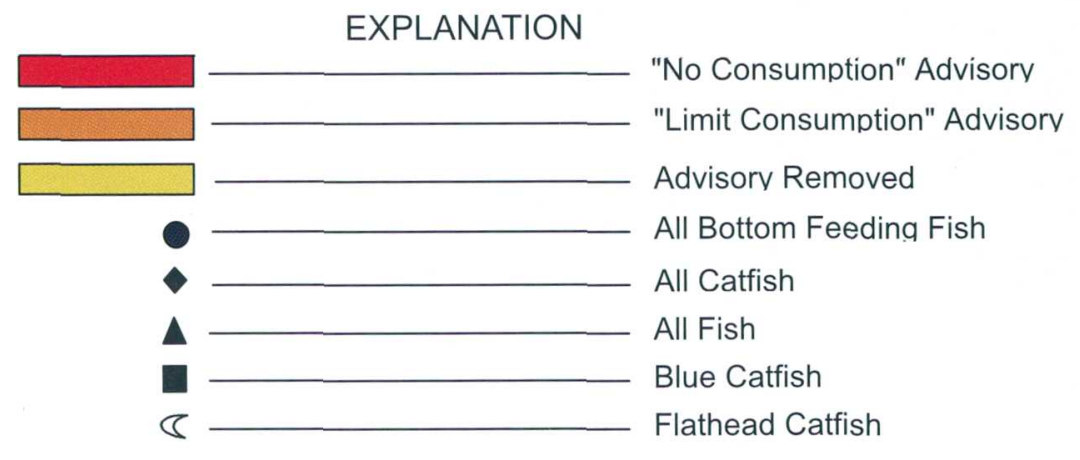

Figure 6. Description of fish advisories for the Leaf and Pascagoula Rivers, 1989-96. 


\section{SUMMARY AND CONCLUSIONS}

In 1989 the MDEQ initiated the MCD Study, and in 1990 officially began coordinating dioxin sampling on the Leaf and Pascagoula Rivers. At the same time the MDEQ initiated the MCD Study, a paper mill on the Leaf River chose to begin monitoring dioxins in aquatic macroinvertebrate (caddisfly) tissue from sites in the study area to determine 2378 TCDD and 2378 TCDF concentrations in secondary food chain organisms (and amounts being transferred through the food chain). Several methods were modified as these studies progressed, with particular regard to fish sampling and how criteria for issuing fish-consumption advisories were developed. Most of the modifications were related to the number of sites sampled, how fish were collected, what fish species were targeted, what fish sizes were targeted, and how advisories were issued.

By 1993, it was evident that 2378 TCDD concentrations were highest in larger, older fish, and that concentrations were higher in flathead

catfish than in other species; however, it was also evident that 2378 TCDD concentrations were decreasing. Weighted mean concentrations of 2378 TCDD in flathead and channel catfish decreased rapidly from approximately $25 \mathrm{pg} / \mathrm{g}$ in the first 2 years of the study to concentrations considered to be background for fish tissue collected in the United States by 1996 . The decrease of 2378 TCDD in fish tissue at site 2.0 that occurred before a decrease occurred at sites downstream indicates that after the major source of 2378 TCDD was eliminated, the sediments may have continued to be a source of 2378 TCDD for a short period; however, as contaminated sediments were flushed from site 2.0 by streamflow, concentrations in fish decreased. All fish-consumption advisories were removed by April 1995. Dioxins were last analyzed in sediments in 1992, and were last analyzed in effluent samples in 1994. Concentrations in both media were near or below detection, and results for more recently collected caddisfly samples were also low.

The presumed cause of the decrease of dioxins in fish tissue was changes the mill made to their bleaching process which reduced dioxins in the effluent. After dioxins were identified in the late 1980 's, modifications were made to the bleaching process through June 1990 which eliminated the use of chlorine, the source of unwanted dioxin by-products. Other changes made to the washing process that may have helped eliminate dioxins were reduced use of wastewater for cleaning, a conversion from defoaming agents which contained dioxin precursors, and the addition of a high pressure diffuser to reduce organic compounds prior to bleaching.

Long-term data for fish and caddisfly tissue indicate that there was a rapid decrease of 2378 TCDD after the mill made changes to the bleaching process. The contaminant was detected in the environment at much lower concentrations and much less frequently after 1990. Three factors that may have influenced, or interacted to accelerate, the decrease of 2378 TCDD in fish tissue after the major source was eliminated are flushing of contaminated sediments by streamflow; depuration by aquatic organisms; and a short half-life of the contaminant in fish tissue, sediment, or both.

\section{REFERENCES}

Barnes, D.G., and Bellin J.S., 1989, Interim procedures for estimating risks associated with exposures to mixtures of chlorinated dibenzo-pdioxins and dibenzofurans (CDDs and CDFs): U.S. Environmental Protection Agency, Risk Assessment Forum, Washington, DC.

Bonn, B.A., 1998, Dioxins and furans in bed sediment and fish tissue of the Willamette Basin, Oregon: Environmental Science and Technology, v. 32, no. 6, p.729-735.

Eisler, R., 1986, Dioxin hazards to fish, wildlife, and invertebrates: a synoptic review. U.S. Fish and Wildlife Service. Biological Report 85, v. 1.8, $37 \mathrm{p}$.

Fiedler, H., Lau, C., Kjeller, L.O., Rappe, C., 1996, Patterns and sources of polychlorinated dibenzop-dioxins and dibenzofurans found in soil and sediment samples in southern Mississippi, Chemosphere, v. 32, p. 421-432.

Hagenmaier, H., and Brunner, H., 1987, Isomer specific analysis of pentachlorophenol and sodium pentachlorophenate for 2,3,7,8substituted PCDD and PCDF at sub-ppb levels: Chemosphere, v. 16, \# 8/9, p. 1759-1764.

Justus, B.G., 1994, Observations on electrofishing techniques for three catfish species in Mississippi: Proceedings of the Annual Conference of the Southeastern American Fish and Wildlife Agencies, p. 524-32. 
Kuehle, D.W., Cook, P.M., Batterman, A.R., Lothenbach, D., and Butterworth, B.C., 1987, Bioavailability of polychlorinated dibenzo-pdioxins and dibenzofurans from contaminated Wisconsin river sediment to carp: Chemosphere v.16, p. 667-679.

Rappe, C., Anderson, R., Bonner, M., Cooper, K., Fielder, H., Howell, F., Kulp, S.E., Lau, C., 1997, PCDDs and PCDFs in soil and river sediment samples from a rural area in the United States of America, Chemosphere, v. 34, p. 1297 1314.

Rappe, C., Anderson, R., Bonner, M., Cooper, K., Fielder, H., Howell, 1998, PCDDs and PCDFs in municipal sewage sludge and effluent from POTWs in the state of Mississippi, USA, Chemosphere, v. 36, p. 315-328.

U.S. Environmental Protection Agency, 1987, The National Dioxin Study: Tiers 3, 5, 6, and 7: U.S. Environmental Protection Agency, Office of Water, Washington, DC, EPA- 440/4-87-003.

U.S. Environmental Protection Agency, 1988, U.S. EPA/Paper Industry Cooperative Dioxin Screening Study: U.S. Environmental Protection Agency, Office of Water, Washington, DC, EPA-440/1-88-025.

U.S. Environmental Protection Agency, 1990a, Polychlorinated dibenzodioxins (PCDDs) and polychlorinated dibenzofurans (PCDFs) by highresolution gas chromatography/high-resolution mass spectrometry (HRGC/HRMS):

Washington, DC, U.S. Environmental Protection Agency, method 8290, 69 p.
U.S. Environmental Protection Agency, 1990b, Tetra- through octa- chlorinated dioxins and furans by isotope dilution high-resolution gas chromatography/high-resolution mass spectrometry (HRGC/HRMS): Washington, DC, U.S. Environmental Protection Agency Method 1613, revision A, 44 p.

U.S. Environmental Protection Agency, 1992a, National study of chemical residues in fish: U.S. Environmental Protection Agency, Office of Water, Washington, DC, EPA/ 823/R-92/008b, vols. 1 and 2.

U.S. Environmental Protection Agency, 1992b, National study of chemical residues in fish fact sheet: U.S. Environmental Protection Agency, Office of Water, Washington, DC, EPA/823/F92/001.

U.S. Environmental Protection Agency, 1993, Interim report on data and methods for assessment of 2,3,7,8-tetrachlorodibenzo-pdioxin risks to aquatic life and associated wildlife: U.S. Environmental Protection Agency, Office of Water, Washington, DC, EPA/ 600/R-93/055, [variously pagenated].

U.S. Food and Drug Administration, 1992, Action levels for poisonous or deleterious substances in human food and animal feed (8/92): Department of Health and Human Services, Washington, DC, $16 \mathrm{p}$. 


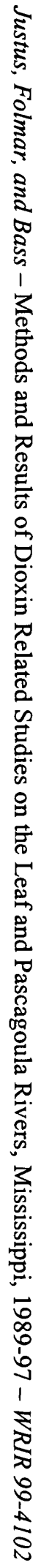

